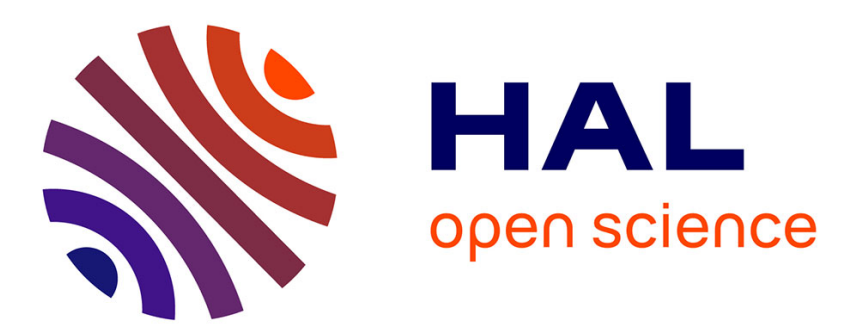

\title{
Adaptable Overhanging Carboxylic Acid Porphyrins Towards Molecular Assemblies through Unusual Coordination Modes
}

Wael Barakat, Ismail Hijazi, Thierry Roisnel, Vincent Dorcet, Bernard Boitrel, Stephane Le Gac

\section{To cite this version:}

Wael Barakat, Ismail Hijazi, Thierry Roisnel, Vincent Dorcet, Bernard Boitrel, et al.. Adaptable Overhanging Carboxylic Acid Porphyrins Towards Molecular Assemblies through Unusual Coordination Modes. European Journal of Inorganic Chemistry, 2019, 2019 (25), pp.3005-3014. 10.1002/ejic.201900539 . hal-02278396

\section{HAL Id: hal-02278396 \\ https://hal-univ-rennes1.archives-ouvertes.fr/hal-02278396}

Submitted on 11 Oct 2019

HAL is a multi-disciplinary open access archive for the deposit and dissemination of scientific research documents, whether they are published or not. The documents may come from teaching and research institutions in France or abroad, or from public or private research centers.
L'archive ouverte pluridisciplinaire HAL, est destinée au dépôt et à la diffusion de documents scientifiques de niveau recherche, publiés ou non, émanant des établissements d'enseignement et de recherche français ou étrangers, des laboratoires publics ou privés. 


\title{
Adaptable Overhanging Carboxylic Acid Porphyrins: Towards Molecular Assemblies Through Unusual Coordination Modes
}

\author{
Wael Barakat ${ }^{[a]}$, Ismail Hijazi ${ }^{[b, c]}$, Thierry Roisnel ${ }^{[a]}$, Vincent Dorcet ${ }^{[a]}$, Bernard Boitrel ${ }^{[[a]}$, Stéphane Le \\ $\mathrm{Gac}^{\star[a]}$
}

\begin{abstract}
A new family of strap porphyrins exhibiting out/in overhanging carboxylic acid stereoisomerism, has been synthesized and investigated for its coordination properties. Their 5,10 linkage allows a significant flexibility of the strap which exhibits various degrees of angulation relatively to the mean porphyrin plane, making the ligand adjustable to the metal it binds. Notably, in the case of $\mathrm{Bi}(\mathrm{III})$, a second sphere of coordination plays a crucial role for the side selective insertion of the large metal ion. As a result, inward and outward orientation of the overhanging carboxylic acid function can be tuned, which is of interest for supramolecular coordination assemblies.
\end{abstract}

\section{Introduction}

Molecular switches based on metal transition complexes keep attracting considerable attention as they constitute promising prototypes of molecular machines and devices ${ }^{[1,2,3,4]}$. In most bistable systems, switching between two states is achieved by a change of the metal ion coordination sphere triggered by an external stimulus. It can also arise from the single translocation of a metal ion itself in a ditopic ligand ${ }^{[5,6]}$ and even, in less common systems, from concerted double translocations of metal ions ${ }^{[7,8]}$. In the particular case of metalloporphyrins, most metal complexes based on the N4-coordination are mononuclear, that is they incorporate one metal cation into one porphyrin, and multimetallic species generated from the porphyrin "N4-box" are much less common. The few reported instances are limited to alkali metal complexes ${ }^{[9,10,11]}$, to transition metalloporphyrins like the $\operatorname{Re}(\mathrm{I}) / \mathrm{Tc}(\mathrm{I}){ }^{[12]}, \mathrm{Rh} / \mathrm{Rh}{ }^{[13]}$, and $\mathrm{Ir} / \mathrm{Ir}{ }^{[14,15]}$ cases, and to the main group dimetallic complexes of $\mathrm{TI}(\mathrm{I}){ }^{[16]}$ and $\mathrm{B}(\mathrm{III}){ }^{[17,18]}$. Most of the time, the usual supramolecular chemistry of these complexes relies on the variation of the coordination sphere of the $\mathrm{N}$-core-bound metal cation ${ }^{[19]}$. However, the situation has evolved when a decade ago, a versatile strategy to form bimetallic species was reported and consisted in appending a binding motif such as a carboxylic acid above the primary coordination site of a porphyrin ${ }^{[20,21]}$. Such a structure was

[a] W. Barakat, Dr. T. Roisnel, Dr. V. Dorcet, Dr. B. Boitrel, Dr. S. Le Gac

Univ Rennes, CNRS, ISCR (Institut des Sciences Chimiques de Rennes), UMR 6226, Rennes F-35000, France

E-mail: stephane.legac@univ-rennes1.fr, bernard.boitrel@univrennes1.fr

https://iscr.univ-rennes1.fr/omc/dr-stephane-le-gac https://iscr.univ-rennes 1 .fr/omc/dr-bernard-boitrel

[b] Dr. I. Hijazi, Faculty of arts and sciences, Lebanese International University LIU/BIU, PO Box 146404 Beirut, Lebanon

[c] Dr. I. Hijazi, Faculty of sciences, Lebanese University, Beirut, Lebanon

Supporting information for this article is given via a link at the end of the document. obtained by formally grafting one or two straps on the diametrically opposed meso positions, namely 5,15 or/and 10,20 of the macrocycle (Figure 1, top line). Based on the study of the resulting homo- and heterobimetallic complexes, our group has evidenced a new coordination mode ${ }^{[22,23,24]}$, new dynamic processes encompassing compartmentalized and noncompartmentalized translocations ${ }^{[25]}$ taking place during stereoselective metallation reactions $[26,27]$ or dynamic constitutional evolution [28], and recently controlled by (photo)redox processes ${ }^{[29,30,31]}$. Most of the properties of these complexes come from the peculiar hanging-atop coordination mode in which a metal cation is "overhung" to the intramolecular carboxylate group, and is stabilized via hydrogen bond(s) between the amide linkage(s) of the strap and its own acetate ligand ${ }^{[22]}$. It is worth noting that as a result of the 5,15 linkage of the strap, the average distance of the carboxylic acid group from the binding site cannot vary significantly. In order to obtain more flexible molecules, we envisaged to synthesize the new ligands 3 and 4 , the analogous isomers of porphyrins 1 and 2 with the very same strap(s) linked on two adjacent meso positions, namely 5,10 and 15,20 (Figure 1, bottom line).
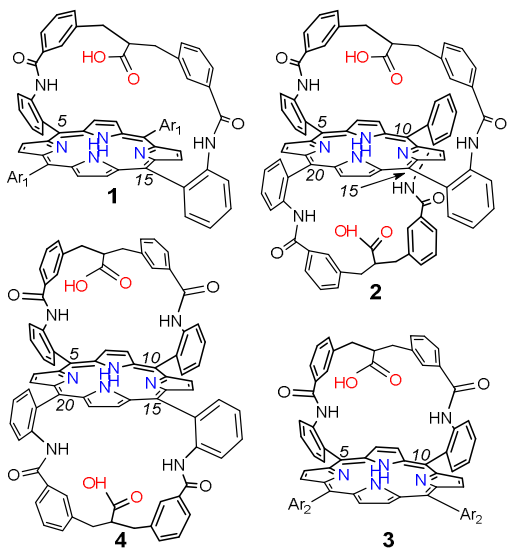

Figure 1. Structure of various strap porphyrins with overhanging carboxylic acid groups $\left(A r_{1}=3,5\right.$-dimethoxyphenyl, $A r_{2}=4$-methoxyphenyl).

Indeed, the ester precursor of porphyrin $\mathbf{4}$ has been synthesized 15 years ago ${ }^{[32]}$ and the solid-state structures of its $\mathrm{Ni}(\mathrm{II}), \mathrm{Zn}$ (II) and $\mathrm{Pb}(\mathrm{II})$ complexes have shown that the mean plane of the straps exhibits variable angles to the mean plane of the macrocycle ranging from $45^{\circ}$ to $90^{\circ}$, clearly indicating the conformational adaptability of this strap [34]. However, the coordination of ligands $\mathbf{3}$ and $\mathbf{4}$ remains unexplored in as much as it is anticipated that porphyrin $\mathbf{3}$ exists as two isomers and porphyrin 4 exists as three isomers according to the relative 
position of the final carboxylic group. Indeed, observing the chemical drawing of precursor porphyrin 9 (Scheme 1), it is obvious that the two ethoxycarbonyl groups are located in different positions. In this simplified arbitrary conformation, the overhanging group labelled "i" (for in) is closer to the center of the porphyrin than the second one (labelled "o" for out) giving rise to typical signatures at different chemical shifts in the proton NMR spectrum ${ }^{[32,33]}$. For instance, in $\mathbf{5}$ (Scheme 2), the "out" ethoxycarbonyl group gives two signals at $3.29 \mathrm{ppm}$ and 0.63 ppm where its "in" analogue leads to the same signature but upfield-shifted at $2.53 \mathrm{ppm}$ and $0.01 \mathrm{ppm}$. It is worth noting that the strap can also adopt a "broken-shape" and a "W-shape" conformation (Figure 2). In the latter, the overhanging group the closest to the center of the porphyrin is the "out "group due to the rotation of carbon atom $\mathrm{C} 2$ around carbon atoms $\mathrm{C} 1$ and $\mathrm{C} 3$ and the subsequent inversion of the relative position of the two overhanging groups. Timely examples of these two conformations were illustrated by the X-ray structures of both ferric and ferrous complexes of closely related ligands in which the second side of the porphyrin was functionalized by a strap bearing a nitrogen base (Figure 2) ${ }^{[35]}$. The first structure (a) indicates that the "in" carboxylate group can coordinate a trivalent ion located c.a. $0.5 \AA$ away from the mean plane of the porphyrin with the strap in a "broken-shape" conformation. The second structure (b) shows that the "out" carboxylic acid group does coordinate a divalent ion located in the mean plane of the porphyrin with the strap in a "W-shape" conformation.

In light of these observations and targeting more particularly supramolecular coordination assemblies with post-transition elements, we describe herein our preliminary findings with " $5-10$ " ligands evidencing strong conformational adaptation in line with an unexpected $\mathrm{Bi}(\mathrm{III})$ coordination mode.
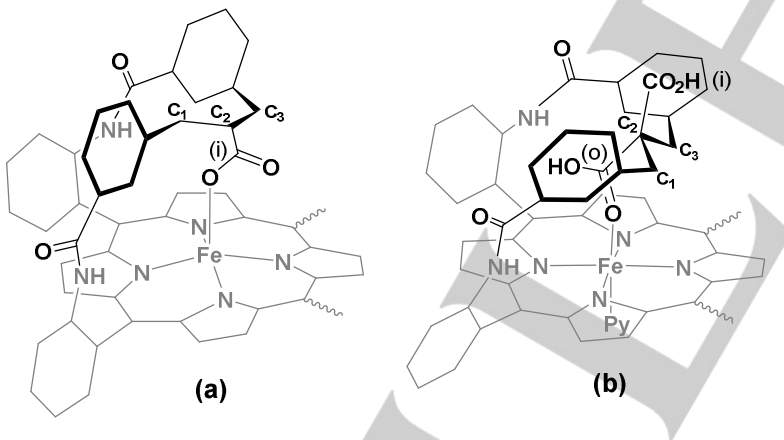

Figure 2. Two actual conformations of the strap reproduced from X-ray structures (a: broken shape with a carboxylate bound ferric heme and $b$ : Wshape with a carboxylic acid bound ferrous heme).

\section{Results and Discussion}

On the one hand, the single strap porphyrins are more difficult to obtain than their bis-strap counterparts as they require the synthesis of the 5,10 isomer of bis-2-nitrophenyl-bis-4methoxyphenylporphyrin 6 (Scheme 1). Actually, the latter was purified as a secondary product from a mixture of 5,10 and 5,15 isomers resulting from the reaction of 5-(4-methoxyphenyl)dipyrromethane with 2-nitrobenzaldehyde in acidic conditions, and further oxidation with DDQ as the 5,15 isomer was also desirable for other purposes ${ }^{[36]}$. First, it was observed that under the experimental conditions used for the reaction, the scrambling reaction was significant. Second, the 5,10 isomer of both porphyrins 6 and 7 were not isolated as a pure compound but only as an enriched mixture in which minor proportions of the 5,15 isomer together with residual scrambled products were found. It is only at the stage of porphyrin $\mathbf{8}$, after the acylation reaction with 3-chloromethyl benzoyl chloride, that the desired compound was obtained as a pure isolated porphyrin. Condensation of diethyl malonate in basic conditions was then performed with porphyrin 8 according to published procedures ${ }^{[37]}$ leading to porphyrin 9 which was saponified by treatment with $\mathrm{KOH}$ in refluxing ethanol for $5 \mathrm{~h}$, followed by heating in DMF to complete mono-decarboxylation, to obtain porphyrins $\mathbf{3 i}$ and $\mathbf{3 0}$ [22]. Porphyrins 30 and $3 \mathbf{i}$ were separated by flash chromatography on silica gel column and eluted with $1.5 \%$ $\mathrm{MeOH} / \mathrm{DCM}(46 \%)$ and $2 \% \mathrm{MeOH} / \mathrm{DCM}(23 \%)$, respectively.
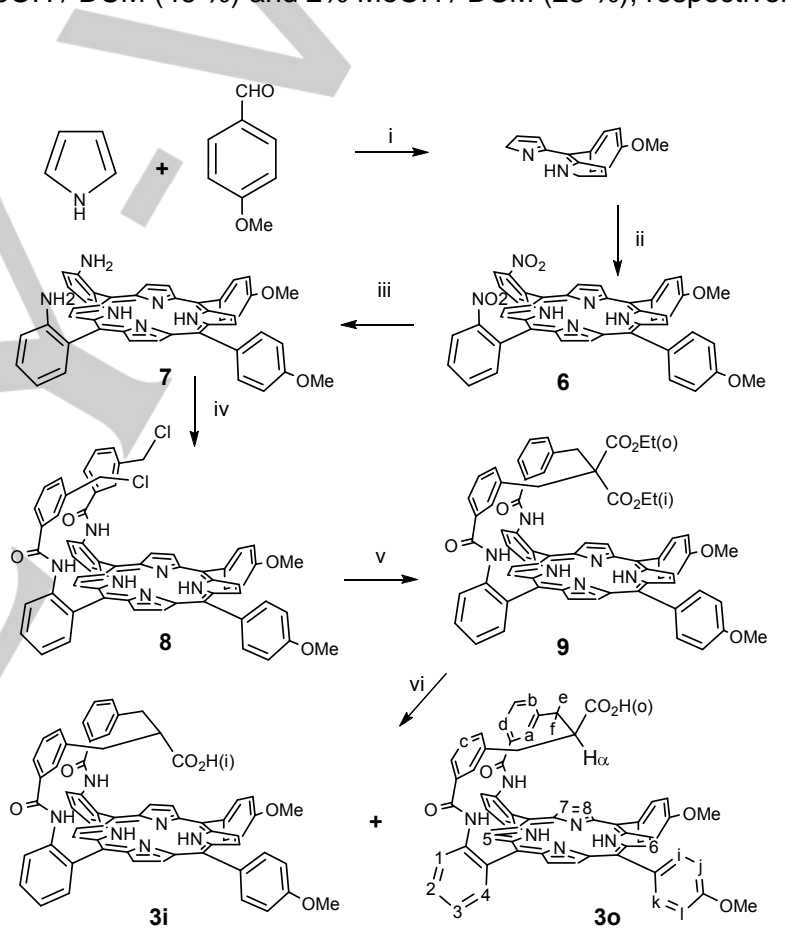

Scheme 1. Synthesis of single strap ligands (30 labelling for NMR assignments). (i) pyrrole (25 equiv.), TFA (0.1 equiv.), $65 \%$; (ii) dry $\mathrm{CH}_{2} \mathrm{Cl}_{2}$, $\mathrm{BF}_{3}-\mathrm{Et}_{2} \mathrm{O}$ (0.1 equiv.), $2 \mathrm{~h}$ at RT, then DDQ; (iii) aq. $\mathrm{HCl}(37 \% \mathrm{w}), \mathrm{SnCl}_{2}(10$ equiv.), $48 \mathrm{~h}$ at RT, $20 \%$; (iv) 3-(chloromethyl)benzoyl chloride (3 equiv.), dry $\mathrm{CH}_{2} \mathrm{Cl}_{2}, \mathrm{Et}_{3} \mathrm{~N}, 1 \mathrm{~h}$ at RT, $24 \%$; (v) $\mathrm{CH}_{2}\left(\mathrm{CO}_{2} \mathrm{Et}\right)_{2}$ (10 equiv.), THF, EtONa, RT, $2 \mathrm{~h}, 83 \%$; (vi) EtOH, THF, KOH, reflux, $5 \mathrm{~h}$, then DMF, $115^{\circ} \mathrm{C}, 2 \mathrm{~h}, 69 \%$.

On the other hand, the access to the bis strap analogous compounds is straightforward as their common precursor $\mathbf{5}$ is readily available at the gram scale ${ }^{[38]}$. Heating 5 with $\mathrm{KOH}$ in EtOH during $9 \mathrm{~h}$, followed by heating in DMF to complete monodecarboxylation, led to the formation of porphyrins 4 with a global yield of $57 \%$, separated and purified by silica gel column chromatography. Porphyrin $\mathbf{4 0 0}$ was eluted first with a mixture of $3 \% \mathrm{MeOH}$ in DCM (36\%), followed by porphyrin 4io eluted with $5 \% \mathrm{MeOH} / \mathrm{DCM}(16 \%)$ and finally came out porphyrin $4 \mathbf{i i}$ 
eluted with $0.1 \% \mathrm{AcOH} / \mathrm{MeOH}(4.9 \%) / \mathrm{DCM}(5 \%)$. For these five new ligands (two single-strap and three bis-strap), the chemical shifts of two different protons $\mathrm{Ha}$ and $\mathrm{H} \alpha$ (see 3o, Scheme 1) can be scrutinized to probe the conformation of the strap(s) keeping in mind that this method, taken alone, leads only to a rough analysis of the conformation of the molecule ${ }^{[39]}$. However, it becomes more precise when either comparing a series of closely related porphyrins for which a restricted type of motion is possible for a given proton. In the present case, the motion of the strap is restricted to the rotation around the two meso aromatic groups and that of the overhanging group is restricted to the rotation around the two benzylic carbon atoms.
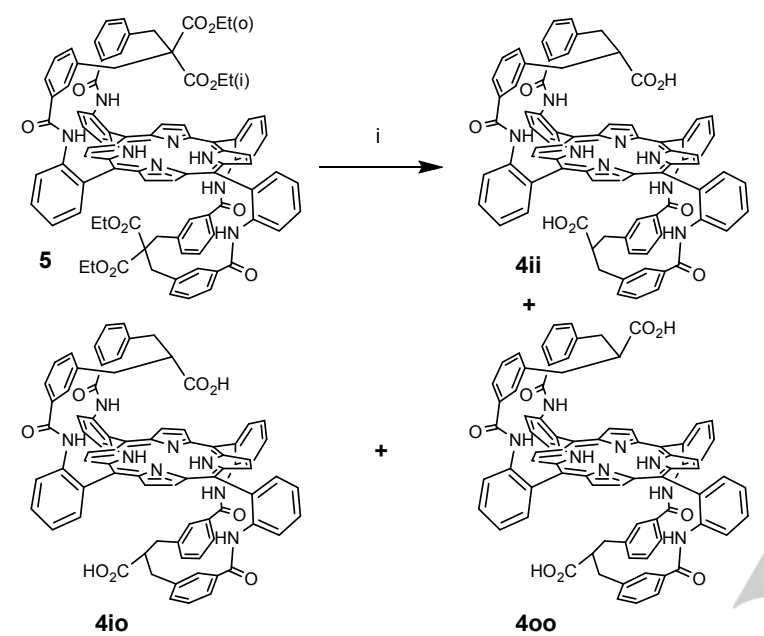

Therefore, we can approximate that $\mathrm{Ha}$ is representative of the inclination of the whole strap over the macrocycle where $\mathrm{H} \alpha$ indicates the orientation of the W-shape part of the strap, all other things being equal. For instance, $\mathrm{H} \alpha$ resonates at -0.26 ppm and 0.56 ppm for $\mathbf{3 i}$ and 30 , respectively. These chemical shifts are not consistent with the chemical drawings of Scheme 1 as the latter would lead to $\mathrm{H} \alpha$ more shielded for 30 . Conversely, the observed chemical shift for $\mathrm{H} \alpha$ is consistent with a "Wshape" strap that inverts the position of the two groups borne by C2. This conformation analysis deduced from proton NMR data was confirmed by the resolution of the X-ray structure of both isomers $\mathbf{3} \mathbf{i}$ (left) and $\mathbf{3 0}$ (right) (Figure 3 ). By a direct comparison of both lateral views, it is obvious that $\mathrm{H} \alpha$ in $\mathbf{3 i}$ is much closer to the centroid of the macrocycle $(3.56 \AA)$ than it is in $30(5.48 \AA)$. However, whereas $\mathrm{Ha}$ protons are located almost at the same distance from the centroid in the solid state structure of both isomers, that is $3.63 / 3.80 \AA$ in $\mathbf{3 i}$ and $3.71 / 3.78 \AA$ in $\mathbf{3 0}$, they do not experience the same chemical shift in solution. They resonate at $3.54 \mathrm{ppm}$ and $4.42 \mathrm{ppm}$ for $\mathbf{3} \mathbf{i}$ and $\mathbf{3 0}$, respectively, indicating that $\mathrm{Ha}$ is closer to the center of the porphyrin in $\mathbf{3 i}$ than in 3o. This suggests a different conformational behaviour in solution compared to the solid state. The same comparison was performed with the three isomers of bis-strap porphyrin $\mathbf{4}$ for which the chemical shifts of protons $\mathrm{Ha}$ and $\mathrm{H} \alpha$ were found significantly different relatively to their single strap counterpart. For instance, Ha resonates at $4.60 \mathrm{ppm}$ in $\mathbf{4 i i}$ (3.54 ppm in 3i) and $5.08 \mathrm{ppm}$ in $\mathbf{4 0 0}$ (4.42 ppm in $\mathbf{3 0}$ ), leading to a difference of $0.5 \mathrm{ppm}$ between both isomers.

Scheme 2. Synthesis of bis strap ligands. (i) $\mathrm{EtOH}, \mathrm{THF}, \mathrm{KOH}$, reflux, $9 \mathrm{~h}$, then DMF, $115^{\circ} \mathrm{C}, 4 \mathrm{~h}, 57 \%$.

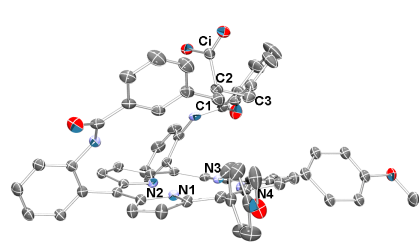

(a)

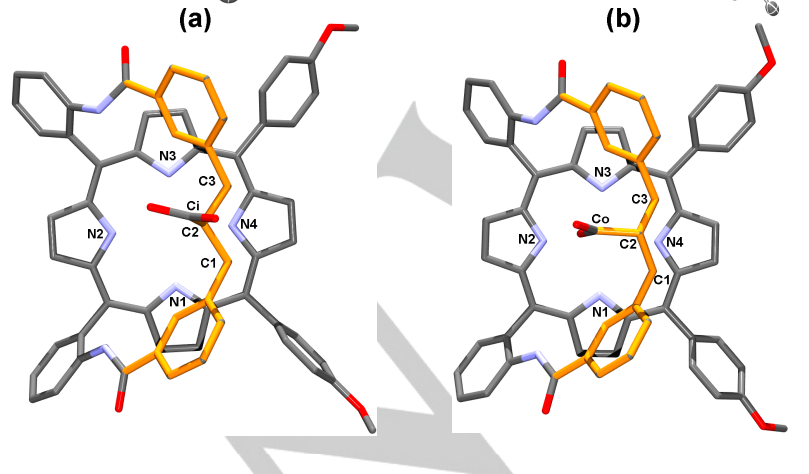

Figure 3. X-ray structures of single-strap porphyrins (a: 3i (CCDC 1902700) and b: 30 (CCDC 1902699); top: ORTEP representation (30\% thermal ellipsoids) and bottom: rods apical view).
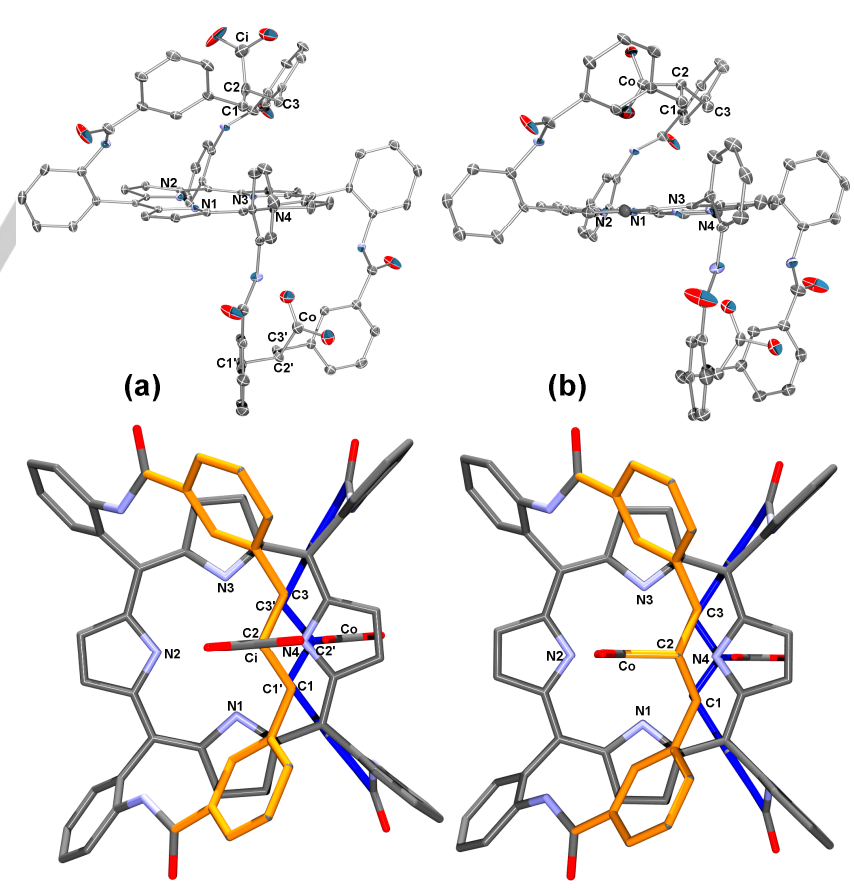

Figure 4. X-ray structures of bis-strap porphyrins (a: 4io (CCDC 1902695) and b: 400 (CCDC 1902697); top: ORTEP representations (30\% thermal ellipsoids) and bottom: rods apical views with foreground strap in orange and background strap in dark blue). 
Even more remarkable is the very same chemical shift of $\mathrm{H} \alpha$ $(0.85 \mathrm{ppm})$ in both $4 \mathrm{ii}$ and $\mathbf{4 0 0}$ whereas they were strongly differentiated in $\mathbf{3 i}$ and $30 \quad(-0.26 \mathrm{ppm}$ and $0.56 \mathrm{ppm}$ respectively). One possible explanation is that the ${ }^{1} \mathrm{H}$ NMR spectra of $4 \mathrm{ii}$ and 400 correspond to average mixtures of different conformations in fast equilibrium on the NMR time scale, making fine conformational analysis complicated (see solid state structures below). In the case of 4io, one observes some similarities in terms of chemical shifts as one $\mathrm{H} \alpha$ at $0.88 \mathrm{ppm}$ but also a significant variation for the second $\mathrm{H} \alpha$ which resonates at
$0.21 \mathrm{ppm}$. For $\mathrm{Ha}$, both chemical shifts in 4io (3.89 and 5.40 $\mathrm{ppm}$ ) are different from those found in the symmetrical compounds 4ii and 400. For two of these bis-strap porphyrins, $X$-ray structures were also resolved and found in agreement with those of their single-strap analogues (Figure 4). They further definitely establish the out/in overhanging carboxylic acid stereoisomerism.

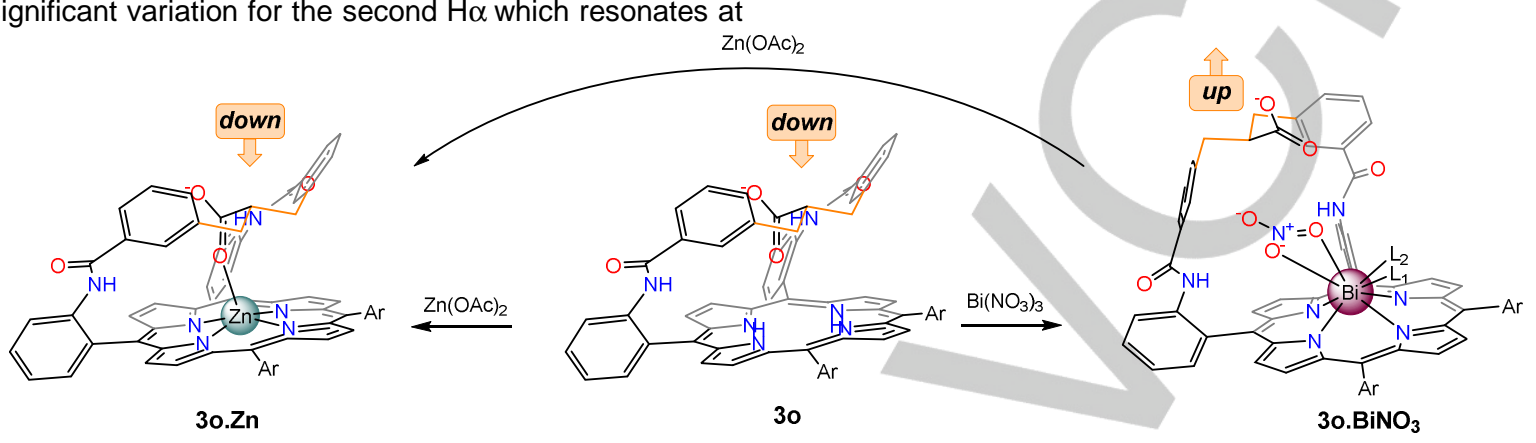

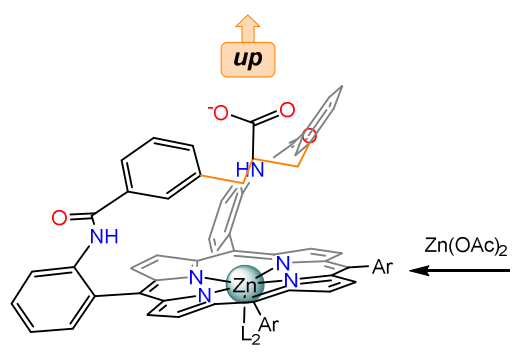

3i.Zn

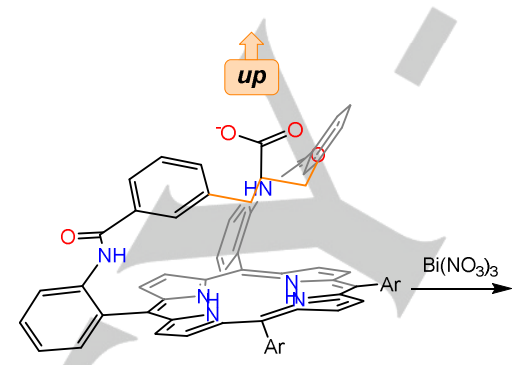

$3 \mathbf{i}$

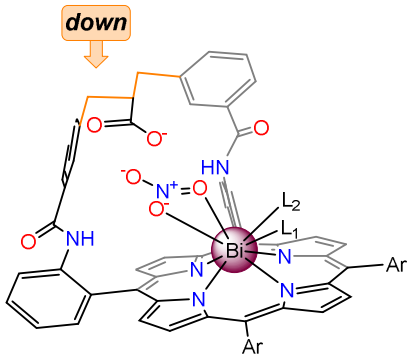

3i. $\mathrm{BiNO}_{3}$

Scheme 3. Coordination behaviour of $\mathbf{3 0}$ and $\mathbf{3 i}$ towards $\mathrm{Zn}(\mathrm{II})$ and $\mathrm{Bi}(\mathrm{III})$ (DMSO- $d_{6}$, DIPEA; $\mathrm{Ar}=4-\mathrm{methoxyphenyl;} \mathrm{L1} \mathrm{=} \mathrm{DMSO;} \mathrm{L2} \mathrm{=} \mathrm{MeOH).}$

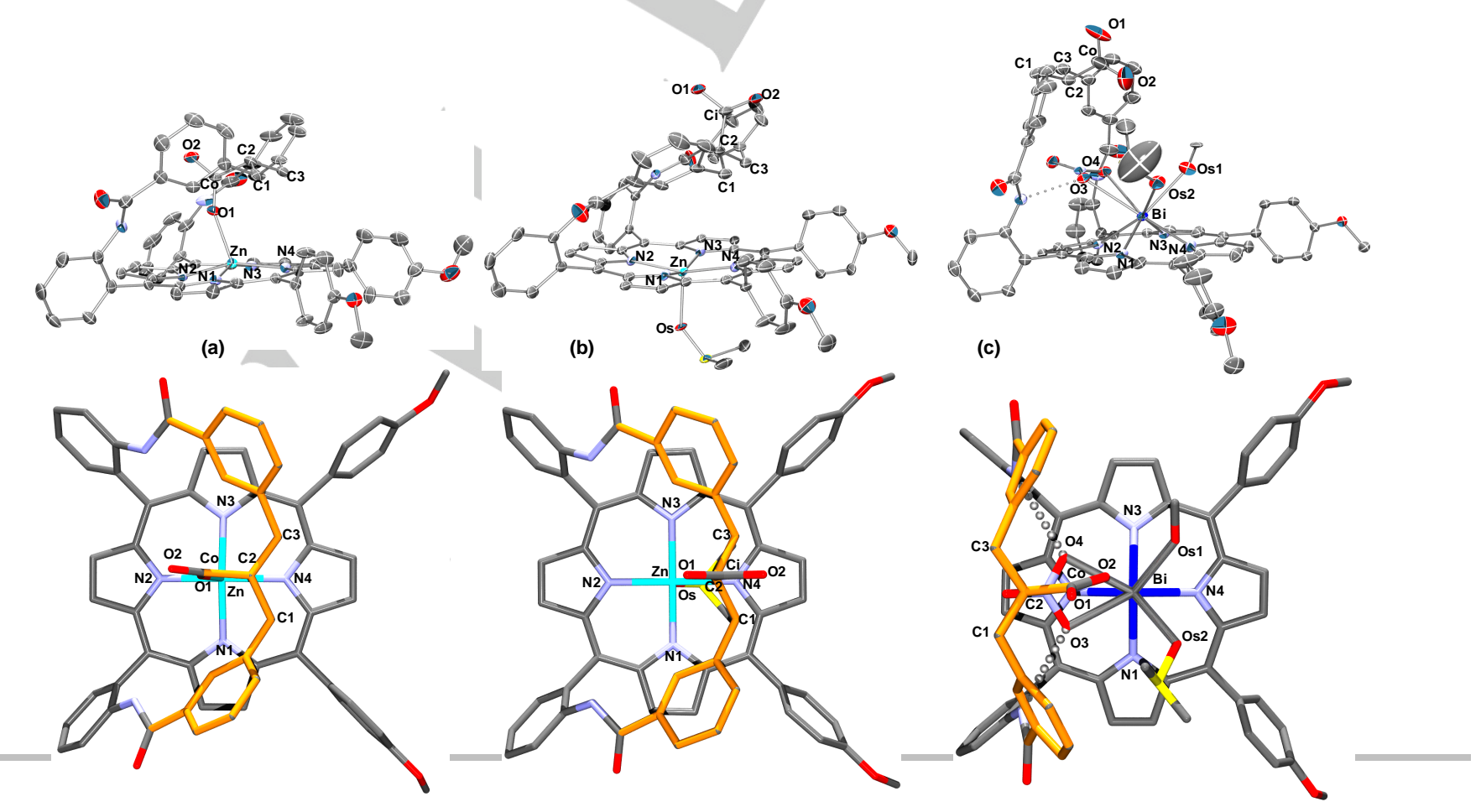


Figure 5. X-ray structures of single-strap porphyrin metal complexes (a: 3o.Zn (CCDC 1902698); b: 3i.Zn (CCDC 1903550); c: 3o.BiNO 3 (CCDC 1912020); top: ORTEP representation (30\% thermal ellipsoids) and bottom: rods apical view).

It is worth noting that the solid state structure of 400 shows one strap bent around $45^{\circ}$ as in 30 but the second one almost at the perpendicular to the mean plane of the macrocycle. This strengthens the hypothesis that its symmetrical ${ }^{1} \mathrm{H} N M R$ spectrum corresponds to an average mixture of conformational isomers in equilibrium.

Hereafter, we describe a preliminary coordination study with the single strap ligands $\mathbf{3 i}$ and $\mathbf{3 0}$, towards $\mathrm{Zn}(\mathrm{II})$ and $\mathrm{Bi}(\mathrm{III})$ cations (Scheme 3). ${ }^{[40]}$ Where the former is known as a small-radius divalent cation with an average out-of-plane displacement around $0.3 \AA$, the latter is much too large to fit into the porphyrin as a trivalent cation and sits c.a. $1.3 \AA$ above the mean porphyrin plane ${ }^{[41]}$. First, comparison of the $\mathrm{X}$-ray crystallographic structures of $\mathbf{3 i} . \mathbf{Z n}$ and $\mathbf{3 0 . Z n}$, both obtained with single crystals grown from DMSO solutions, evidences a clear difference from the view point of $\mathrm{Zn}$ (II) coordination (Figure $5)$. In both cases, the $\mathrm{Zn}$ atom is five-coordinate in a square pyramidal geometry, the coordination sphere involving the $4 \mathrm{~N}$ atoms of the porphyrin and either $\mathrm{O} 1$ from the overhanging $\mathrm{COOH}$ group (for $3 \mathbf{0 . Z n}, \mathrm{O} 1-\mathrm{Zn}=2.085 \AA$ ) or Os from an exogenous DMSO opposite to the strapped side (for $\mathbf{3 i} . \mathbf{Z n}$, Os$\mathrm{Zn}=2.141 \AA$ ) . As a result, the porphyrins adopt opposite slight domed distortions.

Chiefly, the "bent" W-shape conformation of the strap is maintained in both cases (Figure $5 \mathrm{a}$ and $\mathrm{b}$, in orange, apical views). It reveals that the "broken-shape" conformation of the strap, which could be expected with $\mathbf{3 i} . \mathbf{Z n}$, is energetically costly and therefore requires a strong metal-ligand coordination bond with the carboxylic group (such as with $\mathrm{Fe}(\mathrm{III})$, Figure 2a) to counterbalance the steric penalty. Moreover, higher out-of-plane (OOP) displacement of $\mathrm{Fe}$ (III) vs. $\mathrm{Zn}$ (II) may contribute to favor such an interaction (dOOP Fe $0.53 \AA$, dOOP Zn $0.36 \AA$ ).

The "bent" W-shape conformation of $30 . Z n$ was consistently observed in DMSO- $d_{6}$ solution, as deduced from the metalationinduced highfield shift of $\mathrm{Ha}$ protons (Figure 6a,b, $\Delta \delta=-0.69$ ppm). In contrast, the conformational study was less obvious for 3i.Zn. Indeed, a downfield shift of $1.57 \mathrm{ppm}$ of Ha protons upon $\mathrm{Zn}(\mathrm{II})$ coordination (Figure $6 \mathrm{~d}, \mathrm{e}$ ) suggests that the strap is less bent. This could arise from DMSO coordination from one or the other side of the ligand, in a fast exchange regime on the NMR time scale, thus repelling the strap as previously reported for the ester precursors ${ }^{[34]}$. However, variable temperature ${ }^{1} \mathrm{H}$ NMR measurements in $\mathrm{CDCl}_{3} / \mathrm{CD}_{3} \mathrm{OD}$ 9:1 down to $223 \mathrm{~K}$ revealed a bent $\mathrm{W}$-shape conformation, consistent with that of the X-ray structure (a methanol molecule is assumed to bind $\mathrm{Zn}(\mathrm{II})$ opposite to the strapped side).

Contrastingly, the coordination of $\mathrm{Bi}(\mathrm{III})$ led to unexpected behaviours (Scheme 3). For both $\mathbf{3 i}$ and $\mathbf{3 0}$, bismuth insertion proceeds in usual conditions (5 eq of $\mathrm{Bi}\left(\mathrm{NO}_{3}\right)_{3}, 4$ to 16 hours at $85^{\circ} \mathrm{C}$ ), leading quantitatively to a single species. The ${ }^{1} \mathrm{H}$ NMR patterns in DMSO- $d_{6}$ are similar, with a marked deshielding of Ha protons $(\Delta \delta>3 \mathrm{ppm}$, Figure 6 a $v s \mathrm{c}$ and $\mathrm{d} v s \mathrm{f})$, indicating important conformational changes with straps no longer bent over the $\mathrm{N}$-core. These closely related NMR patterns also suggest that bismuth coordination proceeds independently of the in/out $\mathrm{COOH}$ stereoisomerism.

An X-ray structure of the $\mathrm{Bi}(\mathrm{III})$ complex of $\mathbf{3 0}$ was obtained from the NMR tube solution, evidencing a monometallic bismuthnitrato complex $30 \cdot \mathrm{BiNO}_{3}$ (Figure $5 \mathrm{c}$ ). $\mathrm{Bi}(\mathrm{III})$ is bound to the $\mathrm{N}$ core with an out-of-plane displacement of $1.272 \AA$ towards the strapped side of the porphyrin. The coordination sphere involves the four $\mathrm{N}$ atoms of the porphyrin (N1,N2,N3,N4), two $\mathrm{O}$ atoms of solvents (DMSO and methanol, Os1/Os2), and two $\mathrm{O}$ atoms of a bis-hapto nitrato ligand $(\mathrm{O} 3 / \mathrm{O} 4)$. The latter is surrounded by the strap, and stabilized by two $\mathrm{H}$ bonds with the lateral $\mathrm{CONH}$ functions (O3-N/O4-N 3.037/3.081 $\AA$, dashed bonds). This second sphere of coordination is responsible for the sideselective insertion of bismuth, the coordination of $\mathrm{BiNO}_{3}$ on the opposite side being deprived of such stabilization. The strap adopts a "straight" conformation with opposite W-shape orientation vs. the corresponding $\mathrm{Zn}$ (II) complex (Figure $5 \mathrm{c}$ vs a, in orange). This conformation places the closest $\mathrm{O} 2$ atom of the $\mathrm{COOH}$ group at $5.535 \AA$ from the $\mathrm{Bi}$ (III) cation.

Such a coordination mode contrasts with that displayed by the 5 15 related ligands ${ }^{[37,23]}$, whose overhanging carboxylic acid group is bound to $\mathrm{Bi}(\mathrm{III})$. In the present complexes $3 \mathbf{i} . \mathrm{BiNO}_{3}$ and 3o. $\mathrm{BiNO}_{3}$, the $\mathrm{COOH}$ group of the strap is oriented respectively inward and outward, which is opposite to the free bases (Scheme 3). The possible developments of this coordination mode to establish further coordination assemblies is the subject of current investigations.

These 5-10 ligands allow to modulate the interaction of the nitrato counterion with bismuth relatively to non decorated porphyrin complexes exhibiting the monohapto binding mode ${ }^{[42]}$ and to dimeric structures in which the nitrato group is either bishapto without hydrogen bond ${ }^{[43]}$ or acts as a bridging unit ${ }^{[44]}$. They also exhibit a steroselective incorporation of bismuth on the decorated side of the macrocycle clearly indicating an influence of the strap in the metalation process.

Moreover, addition of $\mathrm{Zn}(\mathrm{OAc})_{2}$ to $3 \mathbf{3 o} \cdot \mathrm{BiNO}_{3}$ led to a transmetallation reaction affording quantitatively $30 . \mathrm{Zn}$ (SI). The W-shape inversion in the "straight" to "bent" conformational izomerization of the strap converts the outward to inward orientation of the overhanging $\mathrm{COOH}$ group. This is also an interesting feature targeting responsive supramolecular edifices.

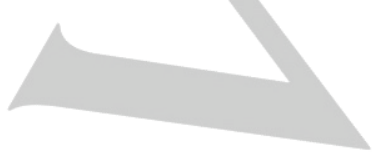




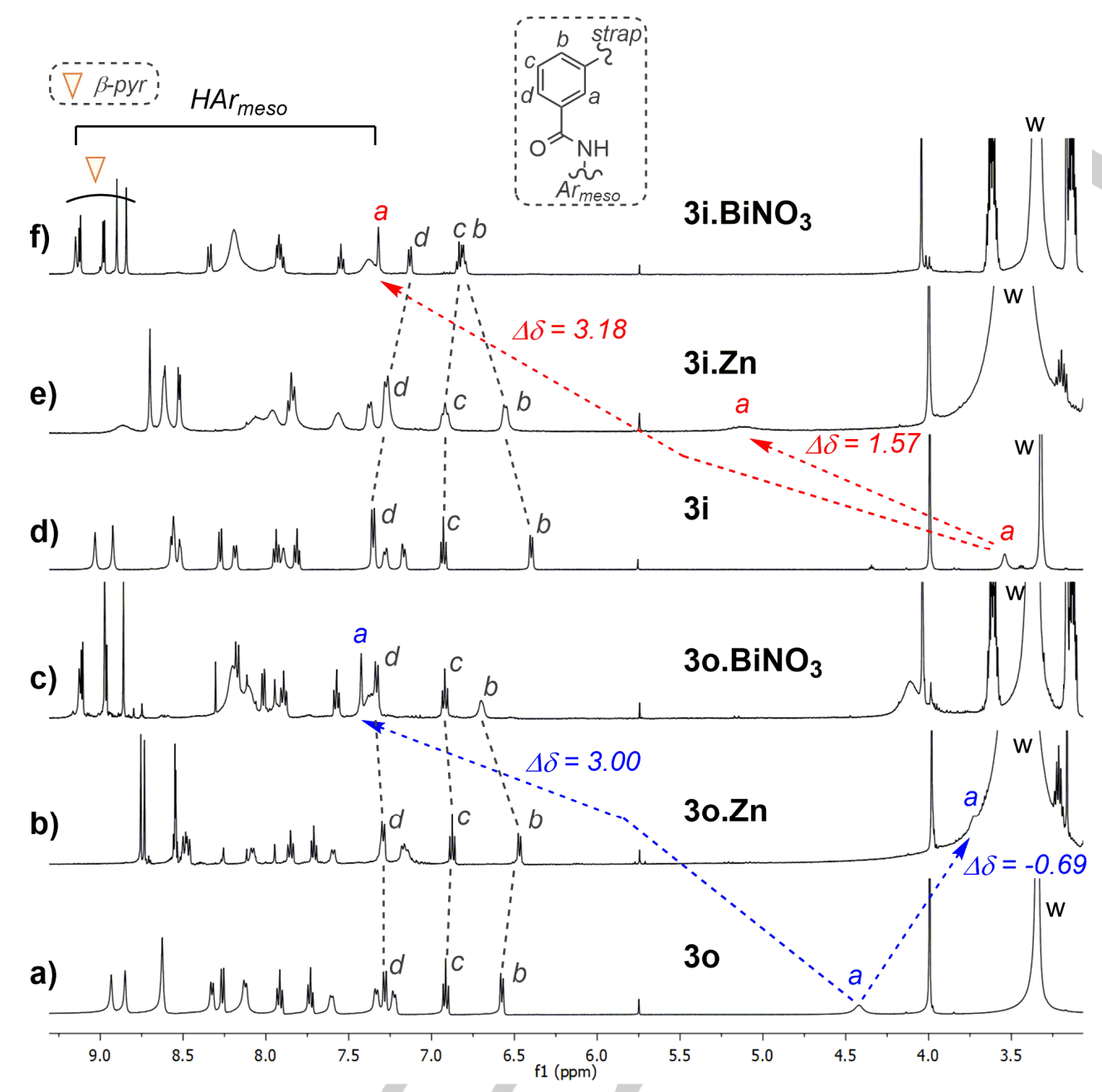

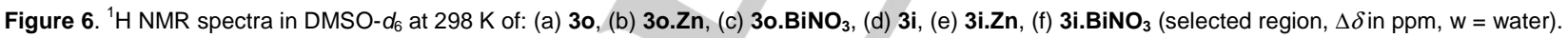

\section{Conclusions}

In conclusion, we have prepared five new strap porphyrin ligands exhibiting out/in overhanging $\mathrm{COOH}$ stereoisomerism. Coordination studies with $\mathrm{Zn}$ (II) and $\mathrm{Bi}$ (III) metal ions have shown important conformational adaptability of the strap resulting in unexpected metal complexes. Whereas in/out $\mathrm{COOH}$ stereoisomerism does not affect so much the bent $\mathrm{W}$-shape conformation with the smallest $\mathrm{Zn}(\mathrm{II})$ cation, with the largest $\mathrm{Bi}(\mathrm{III})$, drastic changes are observed leading to a straight conformation with opposite W-shape. These changes are due to a second sphere of coordination between lateral $\mathrm{CONH}$ functions of the strap and the nitrato ligand of bismuth, responsible for the selective insertion of bismuth from the strapped side, and not to the direct binding of the overhanging $\mathrm{COOH}$ function. The latter adopts opposite inward or outward orientation vs. the free base. Further investigations with large metal ions towards new types of tunable supramolecular coordination assemblies are in progress in our laboratory.

\section{Experimental Section}

\section{General:}

${ }^{1} \mathrm{H}$ and ${ }^{13} \mathrm{C}$ NMR spectra were recorded at respectively $500 \mathrm{MHz}$ and $125 \mathrm{MHz}$ and referenced to the residual protonated solvents. THF was distilled over $\mathrm{Na} /$ benzophenone according to a standard procedure. Other chemicals were used as received without any further purification. All reactions were performed under argon and monitored by TLC (silica, $\mathrm{CH}_{2} \mathrm{Cl}_{2} / \mathrm{CH}_{3} \mathrm{OH}$ ). Column flash chromatography was performed on silica gel (Merck TLC-Kieselgel $60 \mathrm{H}, 15 \mu \mathrm{m}$ ).

Typical procedure for the porphyrins synthesis, here detailed in the case of 3 . Sodium (12 eq) in $\mathrm{EtOH}$ was stirred at room temperature for $30 \mathrm{~min}$ in a two-neck round bottom flask and diethyl malonate (10 eq) was added. After $1 \mathrm{~h}$, the resulting mixture was added to a solution of porphyrin 8 (1 eq) in $\mathrm{CH}_{2} \mathrm{Cl}_{2}$. The reaction mixture was stirred for $2 \mathrm{~h}$ at $\mathrm{RT}$, then water was added. The organic layer was separated from water and 
evaporated under vacuum. Finally, the product was purified on a silica gel chromatography column eluted with $0.03 \%$ $\mathrm{MeOH} / \mathrm{CH}_{2} \mathrm{Cl}_{2}$. The expected compound was obtained in $83 \%$ yield. In the next step, a $100 \mathrm{ml}$ two-neck round bottom flask equipped with a stir bar was charged with $\mathrm{KOH}$ (50 eq) in distilled ethanol. After $30 \mathrm{~min}$, porphyrin 9 (1 eq) was dissolved in THF and slowly added to the reaction mixture, which was refluxed for $5 \mathrm{~h}$. The reaction was quenched by adding distilled water, neutralized by $1 \mathrm{M} \mathrm{HCl}$. Then the product was filtrated and solubilized by $\mathrm{MeOH} / \mathrm{CH}_{2} \mathrm{Cl}_{2}$. Then, the recovered product was heated in DMF for $2 \mathrm{~h}$ at $115{ }^{\circ} \mathrm{C}$. The solvent was removed under vacuum, and the residue was chromatographed on a silica gel column. Compound 30 eluted with $1.5 \% \mathrm{MeOH} / \mathrm{CH}_{2} \mathrm{Cl}_{2}$ was obtained in $46 \%$ yield, and compound $3 \mathbf{i}$ eluted with $2 \%$ $\mathrm{MeOH} / \mathrm{CH}_{2} \mathrm{Cl}_{2}$ was obtained with $23 \%$ yield.

a-5,10-bis-\{2-[(3-chloromethyl)benzoylamino]phenyl\}-15,20bis-(4methoxyphenyl)-porphyrin 8. ${ }^{1} \mathrm{H}$ NMR $\left(\mathrm{CDCl}_{3}, 298 \mathrm{~K}\right.$, $500 \mathrm{MHz}): \delta_{\mathrm{H}}, \mathrm{ppm} 8.94\left(2 \mathrm{H}, \mathrm{d}, J=7.4 \mathrm{~Hz}, \mathrm{H}_{1}\right), 8.92(2 \mathrm{H}, \mathrm{d}, J=$ $\left.4 \mathrm{~Hz}, \mathrm{H}_{7}\right), 8.9\left(2 \mathrm{H}, \mathrm{s}, \mathrm{H}_{5}\right), 8.9\left(2 \mathrm{H}, \mathrm{s}, \mathrm{H}_{6}\right), 8.86(2 \mathrm{H}, \mathrm{d}, J=4.8 \mathrm{~Hz}$, $\left.\mathrm{H}_{8}\right), 8.12\left(2 \mathrm{H}, \mathrm{d}, J=7 \mathrm{~Hz}, \mathrm{H}_{\mathrm{i}}\right), 8.12\left(2 \mathrm{H}, \mathrm{d}, J=7 \mathrm{~Hz}, \mathrm{H}_{\mathrm{k}}\right), 8.08$ $\left(2 \mathrm{H}, \mathrm{d}, J=7.4 \mathrm{~Hz}, \mathrm{H}_{4}\right), 7.89\left(2 \mathrm{H}, \mathrm{t}, J=7.7 \mathrm{~Hz}, \mathrm{H}_{2}\right), 7.75(2 \mathrm{H}, \mathrm{s}$, $\mathrm{NHCO}), 7.57\left(2 \mathrm{H}, \mathrm{t}, J=7.6 \mathrm{~Hz}, \mathrm{H}_{3}\right), 7.36\left(2 \mathrm{H}, \mathrm{d}, J=7.8 \mathrm{~Hz}, \mathrm{H}_{\mathrm{j}}\right)$, $7.36\left(2 \mathrm{H}, \mathrm{d}, J=7.8 \mathrm{~Hz}, \mathrm{H}_{\mathrm{l}}\right), 7.71\left(2 \mathrm{H}, \mathrm{d}, J=7.7 \mathrm{~Hz}, \mathrm{H}_{\mathrm{d}}\right), 6.56$ $\left(2 \mathrm{H}, \mathrm{s}, \mathrm{H}_{\mathrm{a}}\right), 6.39\left(2 \mathrm{H}, \mathrm{d}, J=7.6 \mathrm{~Hz}, \mathrm{H}_{\mathrm{b}}\right), 6.3(2 \mathrm{H}, \mathrm{t}, J=7.3 \mathrm{~Hz}$, $\left.\mathrm{H}_{\mathrm{c}}\right), 4.10\left(6 \mathrm{H}, \mathrm{s}, \mathrm{O}-\mathrm{CH}_{3}\right), 3.48\left(4 \mathrm{H}, \mathrm{m}, \mathrm{CH}_{2 \mathrm{bz}}\right),-2.58(2 \mathrm{H}, \mathrm{s}, \mathrm{NH}$ pyr). ${ }^{13} \mathrm{C} \mathrm{NMR}\left(\mathrm{CDCl}_{3}, 298 \mathrm{~K}, 500 \mathrm{MHz}\right): \delta_{\mathrm{c}}, \mathrm{ppm}, 164.63\left(\mathrm{C}_{\mathrm{co}}\right)$, $135.21\left(C_{4}\right), 135.21\left(C_{i}\right), 135.21\left(C_{k}\right), 133.10\left(C_{5}\right), 133.10\left(C_{6}\right)$, $131.18\left(\mathrm{C}_{8}\right), 130.82\left(\mathrm{C}_{\mathrm{d}}\right), 130.016\left(\mathrm{C}_{7}\right), 129.91\left(\mathrm{C}_{2}\right), 128.11\left(\mathrm{C}_{\mathrm{c}}\right)$, $125.90\left(\mathrm{C}_{\mathrm{b}}\right), 125.81\left(\mathrm{C}_{\mathrm{a}}\right), 122.87\left(\mathrm{C}_{3}\right), 120.08\left(\mathrm{C}_{1}\right), 112.32\left(\mathrm{C}_{\mathrm{j}}\right)$, $112.32\left(\mathrm{C}_{\mathrm{l}}\right), 55.72\left(\mathrm{C}_{\mathrm{OMe}}\right), 44.40\left(\mathrm{C}_{\mathrm{bz}}\right)$. UV-vis $\left(\mathrm{CHCl}_{3}\right): \mathrm{N} / \mathrm{nm}\left(10^{-3}\right.$ $\left.\varepsilon, \mathrm{dm}^{3} . \mathrm{mol}^{-1} . \mathrm{cm}^{-1}\right): 424$ (93.5), 519 (26.9), 556 (10.9), 592 (7.15), 648 (3.7).ESI-HRMS: $\mathrm{m} / \mathrm{z}$ calcd. $1009.30303[\mathrm{M}+\mathrm{H}]^{+}$for $\mathrm{C}_{62} \mathrm{H}_{47} \mathrm{~N}_{6} \mathrm{O}_{4} \mathrm{Cl}_{2}$, found 1009.3028 (0 ppm).

\section{a-5,10-bis-\{2,2'-[3,3'-(2,2-diethoxycarbonyl)propane-1,3-} diyl)benzoylamino]phenyl\}-15,20-bis-(4-methoxyphenyl)porphyrin 9. ${ }^{1} \mathrm{H} \mathrm{NMR}\left(\mathrm{CDCl}_{3}, 298 \mathrm{~K}, 500 \mathrm{MHz}\right): \delta_{\mathrm{H}}, \mathrm{ppm} 8.95$ $\left(2 \mathrm{H}, \mathrm{s}, \mathrm{H}_{5}\right), 8.88\left(2 \mathrm{H}, \mathrm{s}, \mathrm{H}_{6}\right), 8.71\left(2 \mathrm{H}, \mathrm{d}, J=4.3 \mathrm{~Hz}, \mathrm{H}_{7}\right), 8.71$ $\left(2 \mathrm{H}, \mathrm{d}, J=4.3 \mathrm{~Hz}, \mathrm{H}_{8}\right), 8.68\left(2 \mathrm{H}, \mathrm{d}, J=7.9 \mathrm{~Hz}, \mathrm{H}_{1}\right), 8.29(2 \mathrm{H}, \mathrm{d}$, $\left.J=7.4 \mathrm{~Hz}, \mathrm{H}_{4}\right), 8.15\left(2 \mathrm{H}, \mathrm{d}, J=7.6 \mathrm{~Hz}, \mathrm{H}_{\mathrm{k}}\right), 7.91(2 \mathrm{H}, \mathrm{t}, J=7.8$ $\left.\mathrm{Hz}, \mathrm{H}_{2}\right), 7.65\left(2 \mathrm{H}, \mathrm{t}, J=7.7 \mathrm{~Hz}, \mathrm{H}_{3}\right), 7.57\left(2 \mathrm{H}, \mathrm{d}, J=7.9 \mathrm{~Hz}, \mathrm{H}_{\mathrm{d}}\right)$, $7.47\left(2 \mathrm{H}\right.$, broad, $\left.\mathrm{H}_{\mathrm{i}}\right), 7.32(2 \mathrm{H}, \mathrm{s}, \mathrm{NHCO}), 7.27(2 \mathrm{H}, \mathrm{d}, J=7.5$ $\left.\mathrm{Hz}, \mathrm{H}_{\mathrm{l}}\right), 7.10\left(2 \mathrm{H}, \mathrm{d}, J=7.1 \mathrm{~Hz}, \mathrm{H}_{\mathrm{j}}\right), 6.91\left(2 \mathrm{H}, \mathrm{t}, J=7.6 \mathrm{~Hz}, \mathrm{H}_{\mathrm{c}}\right)$, $6.50\left(2 \mathrm{H}, \mathrm{d}, J=7.5 \mathrm{~Hz}, \mathrm{H}_{\mathrm{b}}\right), 4.24\left(2 \mathrm{H}, \mathrm{s}, \mathrm{H}_{\mathrm{a}}\right), 4.06(6 \mathrm{H}, \mathrm{s}, \mathrm{O}-$ $\left.\mathrm{CH}_{3}\right), 2.72\left(2 \mathrm{H}, \mathrm{q}, \mathrm{J}=7.1 \mathrm{~Hz}, \mathrm{CH}_{2}\right.$ ester $), 2.65(2 \mathrm{H}$, broad,

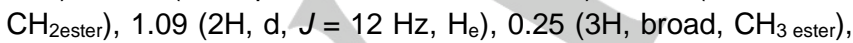
$0.03\left(3 \mathrm{H}, \mathrm{t}, J=7.3 \mathrm{~Hz}, \mathrm{CH}_{3}\right.$ ester $),-0.62\left(2 \mathrm{H}\right.$, broad, $\left.\mathrm{H}_{\mathrm{f}}\right),-2.29$ $\left(2 \mathrm{H}, \mathrm{s}, \mathrm{NH}\right.$ pyr). ${ }^{13} \mathrm{C} \mathrm{NMR}\left(\mathrm{CDCl}_{3}, 298 \mathrm{~K}, 500 \mathrm{MHz}\right): \delta_{\mathrm{c}}, \mathrm{ppm}$ $135.99\left(\mathrm{C}_{\mathrm{i}}\right), 135.82\left(\mathrm{C}_{\mathrm{k}}\right), 135.82\left(\mathrm{C}_{4}\right), 132.99\left(\mathrm{C}_{\mathrm{b}}\right), 130.06\left(\mathrm{C}_{2}\right)$, $128.16\left(\mathrm{C}_{\mathrm{c}}\right), 126.76\left(\mathrm{C}_{\mathrm{d}}\right), 125.65\left(\mathrm{C}_{\mathrm{a}}\right), 123.79\left(\mathrm{C}_{3}\right), 122.13\left(\mathrm{C}_{1}\right)$, $112.33\left(\mathrm{C}_{\mathrm{j}}\right), 112.33\left(\mathrm{C}_{\mathrm{l}}\right), 59.61\left(\mathrm{C}_{\mathrm{CH} 2 \mathrm{ester}}\right), 59.56\left(\mathrm{C}_{\mathrm{CH} 2 \mathrm{ester}}\right), 55.28$ ( $\left.\mathrm{C}_{\text {оме }}\right), 39.89\left(\mathrm{C}_{\mathrm{e}}\right), 39.87\left(\mathrm{C}_{\mathrm{f}}\right), 12.86$ ( $\left.\mathrm{C}_{\mathrm{CH} 3 e s t e r}\right), 12.47$ ( $\left.\mathrm{C}_{\mathrm{CH} 3 \text { ester }}\right)$. UV-vis $\left(\mathrm{CHCl}_{3}\right): \lambda / \mathrm{nm}\left(10^{-3} \varepsilon, \mathrm{dm}^{3} \cdot \mathrm{mol}^{-1} . \mathrm{cm}^{-1}\right): 425$ (35.9), 519 (18.3), 557 (7.6), 593 (4.8), 649 (1.8). ESI-HRMS: $\mathrm{m} / \mathrm{z}$ calcd. 1097.42324 $[\mathrm{M}+\mathrm{H}]^{+}$for $\mathrm{C}_{69} \mathrm{H}_{57} \mathrm{~N}_{6} \mathrm{O}_{8}$, found 1097.4230 (0 ppm). a-5,10-bis- $\{2,2$ '-[3,3'-(2,2-carboxy)propane-1,3diyl)benzoylam-ino]phenyl\}-15,20-bis-(4-methoxyphenyl)porphyrin 3o. ${ }^{1} \mathrm{H}$ NMR (DMSO- $d_{6}, 298 \mathrm{~K}, 500 \mathrm{MHz}$ ): $\delta_{\mathrm{H}}, \mathrm{ppm}$ $8.92\left(2 \mathrm{H}, \mathrm{s}, \mathrm{H}_{5}\right), 8.85\left(2 \mathrm{H}, \mathrm{s}, \mathrm{H}_{6}\right), 8.63\left(2 \mathrm{H}\right.$, broad, $\left.\mathrm{H}_{7}\right), 8.63(2 \mathrm{H}$, broad, $\left.\mathrm{H}_{8}\right), 8.34\left(2 \mathrm{H}, \mathrm{d}, J=7.8 \mathrm{~Hz}, \mathrm{H}_{1}\right), 8.27(2 \mathrm{H}, \mathrm{d}, J=8 \mathrm{~Hz}$, $\left.\mathrm{H}_{4}\right), 8.20\left(2 \mathrm{H}\right.$, broad, NHCO), $8.13\left(2 \mathrm{H}, \mathrm{d}, J=7.8 \mathrm{~Hz}, \mathrm{H}_{\mathrm{k}}\right), 7.91$ $\left(2 \mathrm{H}, \mathrm{t}, J=8.2 \mathrm{~Hz}, \mathrm{H}_{3}\right), 7.73\left(2 \mathrm{H}, \mathrm{t}, J=7.7 \mathrm{~Hz}, \mathrm{H}_{2}\right), 7.63(2 \mathrm{H}, \mathrm{d}, J$ $\left.=7.1 \mathrm{~Hz}, \mathrm{H}_{\mathrm{i}}\right), 7.34\left(2 \mathrm{H}, \mathrm{d}, J=7.5 \mathrm{~Hz}, \mathrm{H}_{\mathrm{l}}\right), 7.28(2 \mathrm{H}, \mathrm{d}, J=8.2$ $\left.\mathrm{Hz}, \mathrm{H}_{\mathrm{d}}\right), 7.23\left(2 \mathrm{H}, \mathrm{d}, J=7.3 \mathrm{~Hz}, \mathrm{H}_{\mathrm{j}}\right), 6.92\left(2 \mathrm{H}, \mathrm{t}, J=7.2 \mathrm{~Hz}, \mathrm{H}_{\mathrm{c}}\right)$, $6.58\left(2 \mathrm{H}, \mathrm{d}, J=7.5 \mathrm{~Hz}, \mathrm{H}_{\mathrm{b}}\right), 4.42\left(2 \mathrm{H}, \mathrm{s}, \mathrm{H}_{\mathrm{a}}\right), 4\left(6 \mathrm{H}, \mathrm{s}, \mathrm{O}-\mathrm{CH}_{3}\right)$, $1.07\left(2 \mathrm{H}\right.$, broad, $\left.\mathrm{H}_{\mathrm{e}}\right), 0.56\left(1 \mathrm{H}, \mathrm{s}, \mathrm{H}_{\mathrm{a}}\right),-0.61\left(2 \mathrm{H}\right.$, broad, $\left.\mathrm{H}_{\mathrm{f}}\right)$, $2.54(2 \mathrm{H}, \mathrm{s}, \mathrm{NH}$ pyr), $\mathrm{H}$ of carboxylic acid not observed. HSQC (DMSO-d $, 300 \mathrm{~K}, 500 \mathrm{MHz}$ ): $\delta_{\mathrm{c}}$, ppm $135.57\left(\mathrm{C}_{\mathrm{i}}\right), 135.52\left(\mathrm{C}_{\mathrm{k}}\right)$, $134.57\left(C_{1}\right), 131.71\left(C_{b}\right), 131.47\left(C_{7}\right), 131.47\left(C_{8}\right), 130.97\left(C_{5}\right)$, $130.10\left(\mathrm{C}_{6}\right), 129.85\left(\mathrm{C}_{3}\right), 128.75\left(\mathrm{C}_{\mathrm{c}}\right), 126.2\left(\mathrm{C}_{\mathrm{a}}\right), 125.82\left(\mathrm{C}_{\mathrm{d}}\right)$, $125.01\left(\mathrm{C}_{4}\right), 124.81\left(\mathrm{C}_{2}\right), 113.13\left(\mathrm{C}_{\mathrm{j}}\right), 112.94\left(\mathrm{C}_{\mathrm{l}}\right), 56.96\left(\mathrm{C}_{\text {оме }}\right)$, $46.88\left(\mathrm{C}_{\alpha}\right), 35.85\left(\mathrm{C}_{\mathrm{e}}\right)$. UV-vis (DMSO): $\mathrm{N} / \mathrm{nm}\left(10^{-3} \varepsilon, \mathrm{dm}^{3} \cdot \mathrm{mol}^{-}\right.$ $\left.{ }^{1} . \mathrm{cm}^{-1}\right) 424$ (137.4), 520 (43.32), 556 (14.87), 593 (8.89), 650 (2.55). ESI-HRMS: $\mathrm{m} / \mathrm{z}$ calcd. $997.37081[\mathrm{M}+\mathrm{H}]^{+}$for $\mathrm{C}_{64} \mathrm{H}_{49} \mathrm{~N}_{6} \mathrm{O}_{6}$, found 997.3711 (0 ppm).

3i. ${ }^{1} \mathrm{H}$ NMR (DMSO- $\left.d_{6}, 298 \mathrm{~K}, 500 \mathrm{MHz}\right): \delta_{\mathrm{H}}, \mathrm{ppm} 9.03(2 \mathrm{H}, \mathrm{s}$, $\left.\mathrm{H}_{5}\right), 8.92\left(2 \mathrm{H}, \mathrm{s}, \mathrm{H}_{6}\right), 8.57\left(2 \mathrm{H}, \mathrm{d}, J=8.1 \mathrm{~Hz}, \mathrm{H}_{1}\right), 8.56(2 \mathrm{H}$, broad, $\left.\mathrm{H}_{7}\right), 8.52\left(2 \mathrm{H}\right.$, broad, $\left.\mathrm{H}_{8}\right), 8.28\left(2 \mathrm{H}, \mathrm{d}, J=8.1 \mathrm{~Hz}, \mathrm{H}_{4}\right)$, $8.19\left(2 \mathrm{H}, \mathrm{d}, J=8.1 \mathrm{~Hz}, \mathrm{H}_{\mathrm{k}}\right), 7.94\left(2 \mathrm{H}, \mathrm{t}, J=7.5 \mathrm{~Hz}, \mathrm{H}_{2}\right), 7.89(2 \mathrm{H}$, s, NHCO), $7.81\left(2 \mathrm{H}, \mathrm{t}, J=7.4 \mathrm{~Hz}, \mathrm{H}_{3}\right), 7.35(2 \mathrm{H}, \mathrm{d}, J=7.8 \mathrm{~Hz}$, $\left.\mathrm{H}_{\mathrm{d}}\right), 7.35\left(2 \mathrm{H}, \mathrm{d}, J=7.8 \mathrm{~Hz}, \mathrm{H}_{\mathrm{l}}\right), 7.28\left(2 \mathrm{H}, \mathrm{d}, J=7.6 \mathrm{~Hz}, \mathrm{H}_{\mathrm{i}}\right), 7.17$ $\left(2 \mathrm{H}, \mathrm{d}, J=7.3 \mathrm{~Hz}, \mathrm{H}_{\mathrm{j}}\right), 6.93\left(2 \mathrm{H}, \mathrm{t}, J=7.7 \mathrm{~Hz}, \mathrm{H}_{\mathrm{c}}\right), 6.40(2 \mathrm{H}, \mathrm{d}, J$ $\left.=7.4 \mathrm{~Hz}, \mathrm{H}_{\mathrm{b}}\right), 4\left(6 \mathrm{H}, \mathrm{s}, \mathrm{O}-\mathrm{CH}_{3}\right), 3.54\left(2 \mathrm{H}, \mathrm{s}, \mathrm{H}_{\mathrm{a}}\right), 0.73(2 \mathrm{H}$, broad, $\left.\mathrm{H}_{\mathrm{e}}\right),-0.26\left(1 \mathrm{H}, \mathrm{s}, \mathrm{H}_{\mathrm{a}}\right),-2.10\left(2 \mathrm{H}\right.$, broad, $\left.\mathrm{H}_{\mathrm{f}}\right),-2.44(2 \mathrm{H}, \mathrm{s}, \mathrm{NHpyr})$, $\mathrm{H}$ of carboxylic acid not observed. HSQC (DMSO- $d_{6}, 298 \mathrm{~K}, 500$ $\mathrm{MHz})$ : $\delta_{\mathrm{c}}, \mathrm{ppm} 135.79\left(\mathrm{C}_{\mathrm{i}}\right), 135.33\left(\mathrm{C}_{\mathrm{k}}\right), 133.54\left(\mathrm{C}_{1}\right), 133.54\left(\mathrm{C}_{7}\right)$, $133.47\left(\mathrm{C}_{8}\right), 131.43\left(\mathrm{C}_{\mathrm{b}}\right), 131.07\left(\mathrm{C}_{5}\right), 129.96\left(\mathrm{C}_{2}\right), 129.82\left(\mathrm{C}_{6}\right)$, $128.40\left(\mathrm{C}_{\mathrm{c}}\right), 126.51\left(\mathrm{C}_{\mathrm{d}}\right), 125.09\left(\mathrm{C}_{3}\right), 125.03\left(\mathrm{C}_{\mathrm{a}}\right), 124.77\left(\mathrm{C}_{4}\right)$, $113.32\left(\mathrm{C}_{\mathrm{l}}\right), 112.87\left(\mathrm{C}_{\mathrm{j}}\right), 55.84\left(\mathrm{Come}_{\mathrm{o}}\right), 48.46\left(\mathrm{C}_{\alpha}\right), 36.88\left(\mathrm{C}_{\mathrm{e}}\right)$, $35.59\left(\mathrm{C}_{\mathrm{f}}\right)$. UV-vis $\left(\mathrm{CHCl}_{3} / \mathrm{MeOH}\right): \lambda / \mathrm{nm}\left(10^{-3} \varepsilon, \mathrm{dm}^{3} \cdot \mathrm{mol}^{-1} \cdot \mathrm{cm}^{-1}\right)$ 425 (81.6), 519 (46.3), 557 (22.8), 593 (10.2), 649 (5.1). ESIHRMS: $m / z$ calcd. $997.37081[\mathrm{M}+\mathrm{H}]^{+}$for $\mathrm{C}_{64} \mathrm{H}_{49} \mathrm{~N}_{6} \mathrm{O}_{6}$, found 997.3707 (0 ppm).

$\alpha-5,10-\beta-15,20$-bis- $\left\{2,2^{\prime}-\left[3,3^{\prime}-\right.\right.$

2(carboxy)propane1,3diyl)dibenz-oylamino]diphenyl\}-

porphyrin 400. ${ }^{1} \mathrm{H}$ NMR (DMSO- $\left.d_{6}, 298 \mathrm{~K}, 500 \mathrm{MHz}\right): \delta_{\mathrm{H}}, \mathrm{ppm}$ $8.89\left(4 \mathrm{H}, \mathrm{s}, \mathrm{H}_{5}\right), 8.58(4 \mathrm{H}, \mathrm{s}, \mathrm{NHCO}), 8.51\left(4 \mathrm{H}, \mathrm{s}, \mathrm{H}_{6}\right), 8.14(4 \mathrm{H}$, $\left.\mathrm{d}, J=8.1 \mathrm{~Hz}, \mathrm{H}_{1}\right), 7.89\left(4 \mathrm{H}, \mathrm{d}, J=7.2 \mathrm{~Hz}, \mathrm{H}_{4}\right), 7.85(4 \mathrm{H}, \mathrm{t}, J=$ $\left.8.1 \mathrm{~Hz}, \mathrm{H}_{2}\right), 7.58\left(4 \mathrm{H}, \mathrm{t}, J=7.3 \mathrm{~Hz}, \mathrm{H}_{3}\right), 7.25(4 \mathrm{H}, \mathrm{d}, J=7.7 \mathrm{~Hz}$, $\left.\mathrm{H}_{\mathrm{d}}\right), 6.92\left(4 \mathrm{H}, \mathrm{t}, J=7.9 \mathrm{~Hz}, \mathrm{H}_{\mathrm{c}}\right), 6.68\left(4 \mathrm{H}, \mathrm{d}, J=8.2 \mathrm{~Hz}, \mathrm{H}_{\mathrm{b}}\right)$, $5.08\left(4 \mathrm{H}, \mathrm{s}, \mathrm{H}_{\mathrm{a}}\right), 1.44\left(4 \mathrm{H}, \mathrm{d}, J=13.7 \mathrm{~Hz}, \mathrm{H}_{\mathrm{e}}\right), 0.35(4 \mathrm{H}$, broad, $\left.\mathrm{H}_{\mathrm{f}}\right), 0.86\left(2 \mathrm{H}, \mathrm{s}, \mathrm{H}_{\mathrm{a}}\right),-2.50(2 \mathrm{H}, \mathrm{s}, \mathrm{NHpyr}), \mathrm{H}$ of carboxylic acids were not observed. HSQC (DMSO- $d_{6}, 298 \mathrm{~K}, 500 \mathrm{MHz}$ ): $\delta_{\mathrm{c}}$, ppm $134.85\left(\mathrm{C}_{4}\right), 133.59\left(\mathrm{C}_{6}\right), 131.69\left(\mathrm{C}_{\mathrm{b}}\right), 129.90\left(\mathrm{C}_{5}\right), 129.55\left(\mathrm{C}_{2}\right)$, $128.20\left(\mathrm{C}_{\mathrm{c}}\right), 126.56\left(\mathrm{C}_{\mathrm{a}}\right), 125.94\left(\mathrm{C}_{1}\right), 125.57\left(\mathrm{C}_{\mathrm{d}}\right), 124.42\left(\mathrm{C}_{3}\right)$, $47.67\left(\mathrm{C}_{\mathrm{a}}\right), 36.14\left(\mathrm{C}_{\mathrm{e}}\right), 36.56\left(\mathrm{C}_{\mathrm{f}}\right)$. UV-vis (DMSO): $\lambda / \mathrm{nm}\left(10^{-3} \varepsilon\right.$, $\left.\mathrm{dm}^{3} \cdot \mathrm{mol}^{-1} \cdot \mathrm{cm}^{-1}\right): 425$ (159), 519 (44.9), 551 (15.1), 591 (18.2),

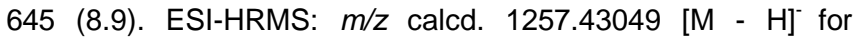
$\mathrm{C}_{80} \mathrm{H}_{57} \mathrm{~N}_{8} \mathrm{O}_{8}$, found 1257.4308 (0 ppm).

4io. ${ }^{1} \mathrm{H}$ NMR (DMSO- $\left.d_{6}, 333 \mathrm{~K}, 500 \mathrm{MHz}\right): \delta_{\mathrm{H}}, \mathrm{ppm} 8.96(2 \mathrm{H}, \mathrm{s}$, $\left.\mathrm{H}_{5}\right), 8.92\left(2 \mathrm{H}, \mathrm{s}, \mathrm{H}_{6}\right), 8.68\left(2 \mathrm{H}, \mathrm{s}, \mathrm{NH}^{\prime} \mathrm{CO}^{\prime}\right), 8.44(2 \mathrm{H}, \mathrm{d}, J=4.4$ 
$\left.\mathrm{Hz}, \mathrm{H}_{7}\right), 8.44\left(2 \mathrm{H}, \mathrm{d}, J=4.9 \mathrm{~Hz}, \mathrm{H}_{8}\right), 8.31\left(2 \mathrm{H}, \mathrm{d}, J=7.3 \mathrm{~Hz}, \mathrm{H}_{1}\right)$, $8.25\left(2 \mathrm{H}, \mathrm{d}, J=8.1 \mathrm{~Hz}, \mathrm{H}_{4}\right), 8.15\left(2 \mathrm{H}, \mathrm{d}, J=7.7 \mathrm{~Hz}, \mathrm{H}_{1}\right), 8(2 \mathrm{H}$, s, NHCO), $7.89\left(2 \mathrm{H}, \mathrm{t}, J=7.7 \mathrm{~Hz}, \mathrm{H}_{3^{\prime}}\right), 7.82\left(2 \mathrm{H}, \mathrm{t}, J=8 \mathrm{~Hz}, \mathrm{H}_{2}\right)$, $7.71\left(2 \mathrm{H}, \mathrm{t}, J=7.9 \mathrm{~Hz}, \mathrm{H}_{2}\right), 7.59\left(2 \mathrm{H}, \mathrm{d}, J=7.3 \mathrm{~Hz}, \mathrm{H}_{4}\right), 7.49$ $\left(2 \mathrm{H}, \mathrm{t}, J=8.1 \mathrm{~Hz}, \mathrm{H}_{3}\right), 7.32\left(2 \mathrm{H}, \mathrm{d}, J=7.7 \mathrm{~Hz}, \mathrm{H}_{d^{\prime}}\right), 7.26(2 \mathrm{H}, \mathrm{d}$, $\left.J=7.9 \mathrm{~Hz}, \mathrm{H}_{\mathrm{d}}\right), 6.91\left(2 \mathrm{H}, \mathrm{t}, J=7.7 \mathrm{~Hz}, \mathrm{H}_{\mathrm{c}}\right), 6.90(2 \mathrm{H}, \mathrm{t}, J=6.9$ $\left.\mathrm{Hz}, \mathrm{H}_{\mathrm{c}^{\prime}}\right), 6.69\left(2 \mathrm{H}, \mathrm{d}, J=7.6 \mathrm{~Hz}, \mathrm{H}_{\mathrm{b}}{ }^{\prime}\right), 6.50\left(2 \mathrm{H}, \mathrm{d}, J=7.1 \mathrm{~Hz}, \mathrm{H}_{\mathrm{b}}\right)$, $5.40\left(2 \mathrm{H}, \mathrm{s}, \mathrm{H}_{\mathrm{a}}\right), 3.89\left(2 \mathrm{H}, \mathrm{s}, \mathrm{H}_{\mathrm{a}^{\prime}}\right), 1.55\left(2 \mathrm{H}, \mathrm{d}, J=13.2 \mathrm{~Hz}, \mathrm{H}_{\mathrm{e}^{\prime}}\right)$, $0.99\left(2 \mathrm{H}\right.$, broad, $\left.\mathrm{H}_{\mathrm{e}}\right), 0.91\left(2 \mathrm{H}\right.$, broad, $\left.\mathrm{H}_{\mathrm{f}^{\prime}}\right), 0.88\left(1 \mathrm{H}, \mathrm{s}, \mathrm{H}_{\alpha^{\prime}}\right), 0.21$ $\left(1 \mathrm{H}, \mathrm{s}, \mathrm{H}_{\mathrm{\alpha}}\right),-1.74\left(2 \mathrm{H}, \mathrm{d}, J=11.5 \mathrm{~Hz}, \mathrm{H}_{\mathrm{f}}\right),-2.35(2 \mathrm{H}, \mathrm{s}, \mathrm{NHpyr})$, $\mathrm{H}$ of carboxylic acids were not observed. HSQC (DMSO- $d_{6}, 333$ $\mathrm{K}, 500 \mathrm{MHz}): \delta_{\mathrm{c}}, \operatorname{ppm} 134.80\left(\mathrm{C}_{4}\right), 133.89\left(\mathrm{C}_{1}\right), 133.16\left(\mathrm{C}_{7}\right)$, $131.46\left(\mathrm{C}_{\mathrm{b}^{\prime}}\right), 131.42\left(\mathrm{C}_{\mathrm{b}}\right), 131.12\left(\mathrm{C}_{8}\right), 129.83\left(\mathrm{C}_{3^{\prime}}\right), 129.70\left(\mathrm{C}_{5}\right)$, $129.70\left(\mathrm{C}_{6}\right), 128.30\left(\mathrm{C}_{\mathrm{c}}\right), 128.30\left(\mathrm{C}_{\mathrm{c}^{\prime}}\right), 126.37\left(\mathrm{C}_{\mathrm{a}^{\prime}}\right), 126.13\left(\mathrm{C}_{\mathrm{d}^{\prime}}\right)$, $125.90\left(\mathrm{C}_{\mathrm{d}}\right), 125.70\left(\mathrm{C}_{\mathrm{a}}\right), 125.63\left(\mathrm{C}_{2}\right), 125.63\left(\mathrm{C}_{1}\right), 124.60\left(\mathrm{C}_{2^{\prime}}\right)$, $124.60\left(\mathrm{C}_{3}\right), 124.60\left(\mathrm{C}_{4^{\prime}}\right), 46.75\left(\mathrm{C}_{\alpha^{\prime}}\right), 36.80\left(\mathrm{C}_{\mathrm{e}}\right), 36.57\left(\mathrm{C}_{\alpha}\right)$, $36.57\left(\mathrm{C}_{\mathrm{f}}\right), 36.23\left(\mathrm{C}_{\mathrm{e}^{\prime}}\right), 35.88\left(\mathrm{C}_{\mathrm{f}}\right)$. UV-vis (DMSO): $\lambda / \mathrm{nm}\left(10^{-3} \varepsilon\right.$, $\left.\mathrm{dm}^{3} \cdot \mathrm{mol}^{-1} \cdot \mathrm{cm}^{-1}\right): 425$ (218.5), 519 (51.3), 552 (10.7), 592 (13.9), 646 (2.27). ESI-HRMS: $\mathrm{m} / \mathrm{z}$ calcd. $1257.43049[\mathrm{M}-\mathrm{H}]^{-}$for $\mathrm{C}_{80} \mathrm{H}_{57} \mathrm{~N}_{8} \mathrm{O}_{8}$, found 1257.4310 (0 ppm).

4ii. ${ }^{1} \mathrm{H}$ NMR (DMSO- $\left.d_{6}, 298 \mathrm{~K}, 500 \mathrm{MHz}\right): \delta_{\mathrm{H}}, \mathrm{ppm} 9\left(4 \mathrm{H}, \mathrm{s}, \mathrm{H}_{5}\right)$, $8.44(4 \mathrm{H}, \mathrm{s}, \mathrm{NHCO}), 8.43\left(4 \mathrm{H}, \mathrm{s}, \mathrm{H}_{6}\right), 8.15(4 \mathrm{H}, \mathrm{d}, J=8.3 \mathrm{~Hz}$, $\left.\mathrm{H}_{1}\right), 8\left(4 \mathrm{H}, \mathrm{d}, J=8.3 \mathrm{~Hz}, \mathrm{H}_{4}\right), 7.87\left(4 \mathrm{H}, \mathrm{t}, J=7.8 \mathrm{~Hz}, \mathrm{H}_{2}\right), 7.64$ $\left(4 \mathrm{H}, \mathrm{t}, J=7.6 \mathrm{~Hz}, \mathrm{H}_{3}\right), 7.31\left(4 \mathrm{H}, \mathrm{d}, J=7.7 \mathrm{~Hz}, \mathrm{H}_{\mathrm{d}}\right), 6.90(4 \mathrm{H}, \mathrm{t}, J$ $\left.=7.5 \mathrm{~Hz}, \mathrm{H}_{\mathrm{c}}\right), 6.59\left(4 \mathrm{H}, \mathrm{d}, J=7.5 \mathrm{~Hz}, \mathrm{H}_{\mathrm{b}}\right), 4.60\left(4 \mathrm{H}, \mathrm{s}, \mathrm{H}_{\mathrm{a}}\right), 1.31$ $\left(4 \mathrm{H}\right.$, broad, $\left.\mathrm{H}_{\mathrm{e}}\right), 0.85\left(2 \mathrm{H}, \mathrm{s}, \mathrm{H}_{\mathrm{a}}\right),-0.69\left(4 \mathrm{H}\right.$, broad, $\left.\mathrm{H}_{\mathrm{f}}\right),-2.43(2 \mathrm{H}$, $\mathrm{s}$, NHpyr), $\mathrm{H}$ of carboxylic acids were not observed. HSQC (DMSO-d $, 298 \mathrm{~K}, 500 \mathrm{MHz}$ ): $\delta_{\mathrm{c}}, \mathrm{ppm}, 134.08\left(\mathrm{C}_{4}\right), 134\left(\mathrm{C}_{6}\right)$, $131.47\left(\mathrm{C}_{\mathrm{b}}\right), 130.01\left(\mathrm{C}_{2}\right), 129.62\left(\mathrm{C}_{5}\right), 128.01\left(\mathrm{C}_{\mathrm{c}}\right), 126.03\left(\mathrm{C}_{\mathrm{d}}\right)$, $125.96\left(\mathrm{C}_{\mathrm{a}}\right), 125.71\left(\mathrm{C}_{1}\right), 124.99\left(\mathrm{C}_{3}\right), 47.94\left(\mathrm{C}_{\mathrm{\alpha}}\right), 36.40\left(\mathrm{C}_{\mathrm{e}}\right)$, $36.40\left(\mathrm{C}_{\mathrm{f}}\right) \cdot\left(\mathrm{CHCl}_{3} / \mathrm{MeOH}\right): \lambda / \mathrm{nm}\left(10^{-3} \varepsilon, \mathrm{dm}^{3} \cdot \mathrm{mol}^{-1} \cdot \mathrm{cm}^{-1}\right) 424$ (116.1), 517 (41.8), 556 (18.7), 587 (17.0), 645 (6.3). ESIHRMS: $m / z$ calcd. $1257.43049[\mathrm{M}-\mathrm{H}]^{-}$for $\mathrm{C}_{80} \mathrm{H}_{57} \mathrm{~N}_{8} \mathrm{O}_{8}$, found 1257.4302 (0 ppm).

\section{Procedures for metal insertion}

A solution (S1) of $\mathrm{Zn}(\mathrm{OAc})_{2}(37.6 \mu \mathrm{mol}, 8.3 \mathrm{mg})$ in DMSO- $d_{6}(500$ $\mu \mathrm{L}$ ) was prepared. $\mathrm{Zn}(\mathrm{II})$ insertion was performed in an NMR tube by mixing either 30 or $3 \mathbf{i}(3.0 \mu \mathrm{mol}, 3.0 \mathrm{mg})$, DMSO- $d_{6}(500 \mu \mathrm{L})$, DIPEA $(17.2 \mu \mathrm{mol}, 3 \mu \mathrm{L})$ and $120 \mu \mathrm{L}$ of solution S1. Heating the NMR tube for $1 \mathrm{~h}$ at $50{ }^{\circ} \mathrm{C}$ led quantitatively to $\mathbf{3 o . Z n}$ and $\mathbf{3 i . Z n}$, as attested by ${ }^{1} \mathrm{H}$ NMR spectra recorded at $298 \mathrm{~K}$ and $353 \mathrm{~K}$, respectively.

3o.Zn. ${ }^{1} \mathrm{H}$ NMR (DMSO- $d_{6}, 298 \mathrm{~K}, 500 \mathrm{MHz}$ ): $\delta_{\mathrm{H}}, \mathrm{ppm} 8.76(2 \mathrm{H}, \mathrm{s}$, $\left.\mathrm{H}_{5}\right), 8.74\left(2 \mathrm{H}, \mathrm{s}, \mathrm{H}_{6}\right), 8.56\left(2 \mathrm{H}, \mathrm{d}, J=4.7 \mathrm{~Hz}, \mathrm{H}_{7}\right), 8.55(2 \mathrm{H}, \mathrm{d}, J=4.4$ $\left.\mathrm{Hz}, \mathrm{H}_{8}\right), 8.50\left(2 \mathrm{H}, \mathrm{d}, J=8.3 \mathrm{~Hz}, \mathrm{H}_{1}\right), 8.47\left(2 \mathrm{H}, \mathrm{d}, J=7 \mathrm{~Hz}, \mathrm{H}_{4}\right), 8.09$ $\left(2 \mathrm{H}, \mathrm{d}, J=7.6 \mathrm{~Hz}, \mathrm{H}_{\mathrm{k}}\right), 7.86\left(2 \mathrm{H}, \mathrm{t}, J=8 \mathrm{~Hz}, \mathrm{H}_{2}\right), 7.72(2 \mathrm{H}, \mathrm{t}, J=7.7$ $\left.\mathrm{Hz}, \mathrm{H}_{3}\right), 7.60\left(2 \mathrm{H}, \mathrm{d}, J=7.2 \mathrm{~Hz}, \mathrm{H}_{\mathrm{i}}\right), 7.31\left(2 \mathrm{H}, \mathrm{d}, J=7.6 \mathrm{~Hz}, \mathrm{H}_{\mathrm{l}}\right), 7.30$ $\left(2 \mathrm{H}, \mathrm{d}, J=7.8 \mathrm{~Hz}, \mathrm{H}_{\mathrm{d}}\right), 7.17\left(2 \mathrm{H}, \mathrm{d}, J=7.9 \mathrm{~Hz}, \mathrm{H}_{\mathrm{j}}\right), 6.88(2 \mathrm{H}, \mathrm{t}, J=$ $\left.7.5 \mathrm{~Hz}, \mathrm{H}_{\mathrm{c}}\right), 6.48\left(2 \mathrm{H}, \mathrm{d}, J=7.4 \mathrm{~Hz}, \mathrm{H}_{\mathrm{b}}\right), 4\left(6 \mathrm{H}, \mathrm{s}, \mathrm{O}-\mathrm{CH}_{3}\right), 3.75(2 \mathrm{H}$, $\left.\mathrm{s}, \mathrm{H}_{\mathrm{a}}\right), 0.84\left(2 \mathrm{H}, J=11 \mathrm{~Hz}, \mathrm{H}_{\mathrm{e}}\right),-0.73\left(2 \mathrm{H}\right.$, broad, $\left.\mathrm{H}_{\mathrm{f}}\right),-0.25(1 \mathrm{H}, \mathrm{s}$, $\left.\mathrm{H}_{\alpha}\right)$. HSQC (DMSO- $\left.d_{6}, 298 \mathrm{~K}, 500 \mathrm{MHz}\right): \delta_{\mathrm{c}}, \mathrm{ppm} 135.88\left(\mathrm{C}_{\mathrm{i}}\right), 135.21$ $\left(\mathrm{C}_{\mathrm{k}}\right), 134.23\left(\mathrm{C}_{4}\right), 132.68\left(\mathrm{C}_{7}\right), 132.43\left(\mathrm{C}_{5}\right), 132.41\left(\mathrm{C}_{6}\right), 131.60\left(\mathrm{C}_{\mathrm{b}}\right)$, $130.20\left(\mathrm{C}_{8}\right), 128.86\left(\mathrm{C}_{2}\right), 128.31\left(\mathrm{C}_{\mathrm{c}}\right), 125.71\left(\mathrm{C}_{\mathrm{d}}\right), 124.30\left(\mathrm{C}_{\mathrm{a}}\right)$, $123.81\left(\mathrm{C}_{3}\right), 122.45\left(\mathrm{C}_{1}\right), 112.39\left(\mathrm{C}_{\mathrm{j}}\right), 112.61\left(\mathrm{C}_{\mathrm{l}}\right), 55.26\left(\mathrm{C}_{\text {оме }}\right)$, $37.91\left(\mathrm{C}_{\mathrm{e}}\right.$ ). UV-vis (DMSO): $\lambda \max , \mathrm{nm}$ (rel. abs). 416 (0.1), 439 (1), $572(0.025)$.

3i.Zn. ${ }^{1} \mathrm{H}$ NMR (DMSO- $\left.d_{6}, 353 \mathrm{~K}, 500 \mathrm{MHz}\right): \delta_{\mathrm{H}}, \mathrm{ppm} 8.81(2 \mathrm{H}, \mathrm{d}, J$ $\left.=7.8 \mathrm{~Hz}, \mathrm{H}_{1}\right), 8.71\left(2 \mathrm{H}, \mathrm{s}, \mathrm{H}_{5}\right), 8.65\left(2 \mathrm{H}, \mathrm{s}, \mathrm{H}_{6}\right), 8.61(2 \mathrm{H}, \mathrm{d}, J=4.5$ $\left.\mathrm{Hz}, \mathrm{H}_{7}\right), 8.55\left(2 \mathrm{H}, \mathrm{d}, J=4.6 \mathrm{~Hz}, \mathrm{H}_{8}\right), 8.12\left(2 \mathrm{H}, \mathrm{d}, J=7.2 \mathrm{~Hz}, \mathrm{H}_{4}\right)$, $7.95\left(2 \mathrm{H}, \mathrm{d}, J=6.9 \mathrm{~Hz}, \mathrm{H}_{\mathrm{i}}\right), 7.93\left(2 \mathrm{H}, \mathrm{d}, J=6.9 \mathrm{~Hz}, \mathrm{H}_{\mathrm{k}}\right), 7.85(2 \mathrm{H}, \mathrm{t}$, $\left.J=7.1 \mathrm{~Hz}, \mathrm{H}_{2}\right), 7.82(2 \mathrm{H}, \mathrm{s}, \mathrm{NHCO}), 7.58\left(2 \mathrm{H}, \mathrm{t}, J=7.3 \mathrm{~Hz}, \mathrm{H}_{3}\right)$, $7.38\left(2 \mathrm{H}, \mathrm{d}, J=7.7 \mathrm{~Hz}, \mathrm{H}_{\mathrm{d}}\right), 7.27\left(2 \mathrm{H}, \mathrm{d}, J=7.7 \mathrm{~Hz}, \mathrm{H}_{\mathrm{j}}\right), 7.27(2 \mathrm{H}, \mathrm{d}$, $\left.J=7.7 \mathrm{~Hz}, \mathrm{H}_{\mathrm{l}}\right), 6.89\left(2 \mathrm{H}, \mathrm{t}, J=7.6 \mathrm{~Hz}, \mathrm{H}_{\mathrm{c}}\right), 6.54(2 \mathrm{H}, \mathrm{d}, J=7.3 \mathrm{~Hz}$, $\left.\mathrm{H}_{\mathrm{b}}\right), 4.94\left(2 \mathrm{H}, \mathrm{s}, \mathrm{H}_{\mathrm{a}}\right), 4.02\left(6 \mathrm{H}, \mathrm{s}, \mathrm{O}-\mathrm{CH}_{3}\right), 1.03\left(2 \mathrm{H}\right.$, broad, $\left.\mathrm{H}_{\mathrm{e}}\right),-0.18$ $\left(2 \mathrm{H}\right.$, broad, $\left.\mathrm{H}_{\mathrm{f}}\right)$. HSQC (DMSO- $\left.d_{6}, 353 \mathrm{~K}, 500 \mathrm{MHz}\right): \delta_{\mathrm{c}}, \mathrm{ppm} 135.66$ $\left(\mathrm{C}_{\mathrm{i}}\right), 135.66\left(\mathrm{C}_{\mathrm{k}}\right), 135.51\left(\mathrm{C}_{1}\right), 134.61\left(\mathrm{C}_{4}\right), 132.88\left(\mathrm{C}_{7}\right), 132.30\left(\mathrm{C}_{\mathrm{b}}\right)$, $131.75\left(\mathrm{C}_{6}\right), 131.71\left(\mathrm{C}_{5}\right), 130.28\left(\mathrm{C}_{8}\right), 129.38\left(\mathrm{C}_{2}\right), 128.02\left(\mathrm{C}_{\mathrm{c}}\right)$, $125.71\left(\mathrm{C}_{\mathrm{d}}\right), 122.97\left(\mathrm{C}_{3}\right), 112.66\left(\mathrm{C}_{\mathrm{l}}\right), 112.66\left(\mathrm{C}_{\mathrm{j}}\right), 56.05$ (Со-оме), $47.80\left(\mathrm{C}_{\mathrm{e}}\right), 47.80\left(\mathrm{C}_{\mathrm{f}}\right)$. UV-vis (DMSO): $\lambda \max , \mathrm{nm}$ (rel. abs). 416 (0.15), 438 (1), 573 (0.043).

A solution (S2) of $\mathrm{Bi}\left(\mathrm{NO}_{3}\right)_{3}(37.6 \mu \mathrm{mol}, 18.2 \mathrm{mg})$ in DMSO- $d_{6}(500$ $\mu \mathrm{L}$ ) was prepared. $\mathrm{Bi}(\mathrm{III})$ insertion was performed in an NMR tube by mixing either $\mathbf{3 0}$ or $\mathbf{3 i}$ ( $3.0 \mu \mathrm{mol}, 3.0 \mathrm{mg})$, DMSO- $d_{6}(500 \mu \mathrm{L})$, DIPEA $(17.2 \mu \mathrm{mol}, 3 \mu \mathrm{L})$ and $200 \mu \mathrm{L}$ of solution S2. Heating the NMR tubes at $85{ }^{\circ} \mathrm{C}$ for respectively 4 and 16 hours led quantitatively to 3o. $\mathrm{BiNO}_{3}$ and $3 \mathrm{i} . \mathrm{BiNO}_{3}$, as attested by ${ }^{1} \mathrm{H}$ NMR spectra recorded at $298 \mathrm{~K}$.

3o. BiNO $_{3}{ }^{1} \mathrm{H}$ NMR (DMSO- $\left.d_{6}, 298 \mathrm{~K}, 500 \mathrm{MHz}\right): \delta_{\mathrm{H}}, \mathrm{ppm} 9.14(2 \mathrm{H}, \mathrm{s}$, $\mathrm{NHCO}), 9.12\left(2 \mathrm{H}, \mathrm{d}, J=4.6 \mathrm{~Hz}, \mathrm{H}_{7}\right), 8.98\left(2 \mathrm{H}, \mathrm{s}, \mathrm{H}_{5}\right), 8.97(2 \mathrm{H}, \mathrm{d}, J$ $\left.=4.7 \mathrm{~Hz}, \mathrm{H}_{8}\right), 8.87\left(2 \mathrm{H}, \mathrm{s}, \mathrm{H}_{6}\right), 8.21\left(2 \mathrm{H}\right.$, broad, $\left.\mathrm{H}_{\mathrm{k}}\right), 8.18(2 \mathrm{H}, \mathrm{d}, J=$ $\left.8.4 \mathrm{~Hz}, \mathrm{H}_{1}\right), 8.11\left(2 \mathrm{H}\right.$, broad, $\left.\mathrm{H}_{1}\right), 7.90\left(2 \mathrm{H}, \mathrm{d}, J=7.4 \mathrm{~Hz}, \mathrm{H}_{4}\right), 7.90$ $\left(2 \mathrm{H}, \mathrm{t}, J=7.4 \mathrm{~Hz}, \mathrm{H}_{2}\right), 7.58\left(2 \mathrm{H}, \mathrm{t}, J=7.5 \mathrm{~Hz}, \mathrm{H}_{3}\right), 7.42\left(2 \mathrm{H}, \mathrm{s}, \mathrm{H}_{\mathrm{a}}\right)$, $7.34\left(2 \mathrm{H}, \mathrm{d}, J=7.8 \mathrm{~Hz}, \mathrm{H}_{\mathrm{d}}\right), 7.34\left(2 \mathrm{H}, \mathrm{d}, J=7.8 \mathrm{~Hz}, \mathrm{H}_{\mathrm{j}}\right), 7.28(2 \mathrm{H}, \mathrm{d}$, $\left.J=7.6 \mathrm{~Hz}, \mathrm{H}_{\mathrm{i}}\right), 6.94\left(2 \mathrm{H}, \mathrm{t}, J=7.7 \mathrm{~Hz}, \mathrm{H}_{\mathrm{c}}\right), 6.70\left(2 \mathrm{H}\right.$, broad, $\left.\mathrm{H}_{\mathrm{b}}\right)$, $4.05\left(6 \mathrm{H}, \mathrm{s}, \mathrm{O}-\mathrm{CH}_{3}\right), 2.47\left(2 \mathrm{H}\right.$, broad, $\left.\mathrm{H}_{\mathrm{e}}\right), 2.31(2 \mathrm{H}, \mathrm{d}, J=11.2 \mathrm{~Hz}$, $\left.\mathrm{H}_{\mathrm{f}}\right), 1.00\left(1 \mathrm{H}, \mathrm{s}, \mathrm{H}_{\mathrm{a}}\right) \cdot \mathrm{HSQC}\left(\mathrm{DMSO}-d_{6}, 298 \mathrm{~K}, 500 \mathrm{MHz}\right): \delta_{\mathrm{c}}, \mathrm{ppm}$ $136.48\left(\mathrm{C}_{\mathrm{i}}\right), 134.72\left(\mathrm{C}_{4}\right), 132.86\left(\mathrm{C}_{7}\right), 132.65\left(\mathrm{C}_{5}\right), 131.72\left(\mathrm{C}_{6}\right)$, $131.71\left(\mathrm{C}_{\mathrm{b}}\right), 131.89\left(\mathrm{C}_{8}\right), 130.33\left(\mathrm{C}_{\mathrm{a}}\right), 129.13\left(\mathrm{C}_{2}\right), 127.94\left(\mathrm{C}_{\mathrm{c}}\right)$, $127.07\left(\mathrm{C}_{\mathrm{d}}\right), 125.01\left(\mathrm{C}_{\mathrm{k}}\right), 124.84\left(\mathrm{C}_{1}\right), 123.65\left(\mathrm{C}_{3}\right), 113.44\left(\mathrm{C}_{\mathrm{l}}\right)$, $113.12\left(\mathrm{C}_{\mathrm{j}}\right), 55.94\left(\mathrm{C}_{\text {омe }}\right), 51.91\left(\mathrm{C}_{\alpha}\right), 40.82\left(\mathrm{C}_{\mathrm{e}}\right), 40.44\left(\mathrm{C}_{\mathrm{f}}\right)$. UV-vis (DMSO): Amax, nm (rel. abs). 354 (0.24), 474 (1), 606 (0.043), 654 (0.06).

3i.BiNO ${ }_{3}{ }^{1} \mathrm{H}$ NMR (DMSO- $d_{6}, 298 \mathrm{~K}, 500 \mathrm{MHz}$ ): $\delta_{\mathrm{H}}, \mathrm{ppm} 9.15(2 \mathrm{H}, \mathrm{s}$, $\mathrm{NHCO}), 9.12\left(2 \mathrm{H}, \mathrm{d}, J=4.5 \mathrm{~Hz}, \mathrm{H}_{7}\right), 8.98\left(2 \mathrm{H}, \mathrm{d}, J=4.6 \mathrm{~Hz}, \mathrm{H}_{8}\right)$, $8.90\left(2 \mathrm{H}, \mathrm{s}, \mathrm{H}_{5}\right), 8.84\left(2 \mathrm{H}, \mathrm{s}, \mathrm{H}_{6}\right), 8.34\left(2 \mathrm{H}, \mathrm{d}, J=8.7 \mathrm{~Hz}, \mathrm{H}_{1}\right), 8.19$ $\left(2 \mathrm{H}\right.$, broad, $\left.\mathrm{H}_{\mathrm{k}}\right), 8.19\left(2 \mathrm{H}\right.$, broad, $\left.\mathrm{H}_{\mathrm{i}}\right), 7.93\left(2 \mathrm{H}, \mathrm{m}, \mathrm{H}_{2}\right), 7.91(2 \mathrm{H}, \mathrm{m}$, $\left.\mathrm{H}_{4}\right), 7.55\left(2 \mathrm{H}, \mathrm{t}, J=7.5 \mathrm{~Hz}, \mathrm{H}_{3}\right), 7.55\left(2 \mathrm{H}\right.$, broad, $\left.\mathrm{H}_{1}\right), 7.55(2 \mathrm{H}$, broad, $\left.\mathrm{H}_{\mathrm{j}}\right), 7.32\left(2 \mathrm{H}, \mathrm{s}, \mathrm{H}_{\mathrm{a}}\right), 7.13\left(2 \mathrm{H}, \mathrm{d}, J=7.5 \mathrm{~Hz}, \mathrm{H}_{\mathrm{d}}\right), 6.84\left(2 \mathrm{H}, \mathrm{m}, \mathrm{H}_{\mathrm{c}}\right)$, $6.81\left(2 \mathrm{H}, \mathrm{m}, \mathrm{H}_{\mathrm{b}}\right), 4.04\left(6 \mathrm{H}, \mathrm{s}, \mathrm{O}-\mathrm{CH}_{3}\right), 2.74\left(1 \mathrm{H}, \mathrm{s}, \mathrm{H}_{\mathrm{a}}\right), 2.06(2 \mathrm{H}$, broad, $\left.\mathrm{H}_{\mathrm{e}}\right), 1.74\left(2 \mathrm{H}\right.$, broad, $\left.\mathrm{H}_{\mathrm{f}}\right)$. HSQC (DMSO- $\left.d_{6}, 298 \mathrm{~K}, 500 \mathrm{MHz}\right)$ : $\delta_{c}$, ppm $134.01\left(\mathrm{C}_{2}\right), 133.15\left(\mathrm{C}_{\mathrm{b}}\right), 132.25\left(\mathrm{C}_{7}\right), 131.44\left(\mathrm{C}_{6}\right), 131.30$ $\left(\mathrm{C}_{5}\right), 130.90\left(\mathrm{C}_{8}\right), 128.63\left(\mathrm{C}_{4}\right), 127.48\left(\mathrm{C}_{\mathrm{c}}\right), 126.84\left(\mathrm{C}_{\mathrm{a}}\right), 125.79\left(\mathrm{C}_{\mathrm{d}}\right)$, $123.13\left(\mathrm{C}_{1}\right), 122.10\left(\mathrm{C}_{3}\right), 112.52\left(\mathrm{C}_{\mathrm{j}}\right), 112.52\left(\mathrm{C}_{\mathrm{l}}\right), 56.79\left(\mathrm{C}_{\text {оме }}\right)$, $37.09\left(\mathrm{C}_{\mathrm{f}}\right)$. UV-vis (DMSO): $\lambda \max , \mathrm{nm}$ (rel. abs). 355 (0.21), 474 (1), 609 (0.034), 660 (0.051).

\section{X-ray Crystallographic Studies.}

Collected data obtained with a D8 VENTURE Bruker AXS diffractometer (founded by FEDER) equipped with a (CMOS) PHOTON 100 detector, Mo-Ka radiation $(\lambda=0.71073 \AA$, multilayer monochromator), $T=150(2) \mathrm{K}$. The structures were solved by dual-space algorithm using the SHELXT program ${ }^{[45]}$, and then refined with full-matrix least-square methods based on $F^{2}(S H E L X L){ }^{[46]}$. Except otherwise stated, the contribution of the disordered solvents to the calculated structure factors was estimated following the BYPASS algorithm ${ }^{[47]}$, implemented as the SQUEEZE option in PLATON ${ }^{[48]}$. A new data set, free of 
solvent contribution, was then used in the final refinement. All non-hydrogen atoms were refined with anisotropic atomic displacement parameters. $\mathrm{H}$ atoms were finally included in their calculated positions and treated as riding on their parent atom with constrained thermal parameters.

3i: CCDC 1902700, $\mathrm{C}_{64} \mathrm{H}_{48} \mathrm{~N}_{6} \mathrm{O}_{6}, M=997.08$. Monoclinic $P 2_{1} / c$ (I.T.\#14), $a=15.1962(5), b=22.7866(9), c=17.5837(8) \AA ̊ ., \beta=$ $115.0770(10){ }^{\circ}, V=5514.8(4) \AA^{3} . Z=4, d=1.201 \mathrm{~g} . \mathrm{cm}^{-3}, \mu=$ $0.078 \mathrm{~mm}^{-1}$. The contribution of the disordered solvents to the structure factors was calculated by the PLATON SQUEEZE procedure ${ }^{[49]}$ and then taken into account in the final SHELXL2014 least-square refinement. A final refinement on $F^{2}$ with 12643 unique intensities and 657 parameters converged at $\omega R\left(F^{2}\right)=0.1964(R(F)=0.0749)$ for 9173 observed reflections with $I>2 \sigma(I)$.

3o: CCDC 1902699, $\mathrm{C}_{64} \mathrm{H}_{48} \mathrm{~N}_{6} \mathrm{O}_{6} \cdot \mathrm{C}_{2} \mathrm{H}_{6} \mathrm{OS}, M=1075.21$. Triclinic $P$-1 (I.T.\#2), $a=14.1179(13), b=18.2349(15), c=23.675(2) \AA$, $\alpha=89.848(3), \beta=73.442(3), \gamma=67.308(3) \circ, V=5350.0(9)$ $\AA^{3} . Z=4, d=1.335 \mathrm{~g} \cdot \mathrm{cm}^{-3}, \mu=0.125 \mathrm{~mm}^{-1}$. Except for nitrogen and oxygen linked hydrogen atoms that were introduced in the structural model through Fourier difference maps analysis, $\mathrm{H}$ atoms were finally included in their calculated positions and treated as riding on their parent atom with constrained thermal parameters. A final refinement on $F^{2}$ with 24386 unique intensities and 1479 parameters converged at $\omega R\left(F^{2}\right)=0.1369$ $(R(F)=0.0540)$ for 18231 observed reflections with $I>2 \sigma(I)$.

4io: CCDC 1902695, $\mathrm{C}_{81} \mathrm{H}_{59} \mathrm{Cl}_{3} \mathrm{~N}_{8} \mathrm{O}_{8}, M=1378.71$. Monoclinic $P 2_{1} / m$ (I.T.\#11), $a=11.734(3), b=16.695(3), c=21.233(5) \AA$ $=98.139(8){ }^{\circ}, V=4117.7(15) \AA^{3} . Z=2, d=1.112 \mathrm{~g} \cdot \mathrm{cm}^{-3}, \mu=$ $0.166 \mathrm{~mm}^{-1}$. A final refinement on $F^{2}$ with 9543 unique intensities and 469 parameters converged at $\omega R_{F}{ }^{2}=0.2598\left(R_{F}=0.0951\right)$ for 6845 observed reflections with $I>2 \sigma(I)$.

400: $\operatorname{CCDC}$ 1902697, $\left(\mathrm{C}_{80} \mathrm{H}_{54} \mathrm{~N}_{8} \mathrm{O}_{8} \cdot 3\left(\mathrm{CHCl}_{3}\right) \cdot 4(\mathrm{O})\right) ; \quad M=$ 1677.41. monoclinic $P 2_{1} / m$ (I.T.\#11), $a=11.678(3), \quad b=$ 16.682(5), $c=20.765(6) \AA, \beta=98.283(9) \circ, V=4003(2) \AA^{3} . Z=$ $2, d=1.392{\mathrm{~g} . \mathrm{cm}^{-3}}^{-3} \mu=0.382 \mathrm{~mm}^{-1}$. All non-hydrogen atoms were refined with anisotropic atomic displacement parameters. $\mathrm{H}$ atoms were finally included in their calculated positions and treated as riding on their parent atom with constrained thermal parameters. A final refinement on $F^{2}$ with 9239 unique intensities and 526 parameters converged at $\omega R_{F}^{2}=0.3961\left(R_{F}=0.1599\right)$ for 3507 observed reflections with $I>2 \sigma(I)$. The small size crystal did not diffract well. As a result, the dataset quality was not good as revealed by the reliability factors of the refinement (A and $B$ alerts). This also results in the impossibility to determine the position of the hydrogen atoms on water molecules. However, as the atom position and ADP of the porphyrin have been well determined without any constrain with no $\mathrm{A}$ or $\mathrm{B}$ alert in the checkcif related to these atoms, we consider this structure worth to rely on.

3o.Zn: $\quad$ CCDC 1902698, $\quad \mathrm{C}_{64} \mathrm{H}_{45} \mathrm{~N}_{6} \mathrm{O}_{6} \mathrm{Zn}, \quad M=$ 1059.43. Orthorhombic $P c a 2_{1}$ (I.T.\#29), $a=25.200$ (2), $b=$ 15.1085(10), $c=15.9687(11) \AA, V=6079.8(8) \AA^{3} . Z=4, d=$ $1.157 \mathrm{~g} \mathrm{~cm}^{-3}, \mu=0.456 \mathrm{~mm}^{-1}$. A final refinement on $F^{2}$ with 13789 unique intensities and 696 parameters converged at $\omega R\left(F^{2}\right)=0.1351(R(F)=0.0583)$ for 10959 observed reflections with $I>2 \sigma(I)$.
3i.Zn: $\quad$ CCDC 1903550, $\quad \mathrm{C}_{66} \mathrm{H}_{52} \mathrm{~N}_{6} \mathrm{O}_{7} \mathrm{SZn}, \quad M=$ 1138.56. Monoclinic $P 2_{1} / m$ (I.T.\#11), $a=11.6881(15), \quad b=$ 17.235(2), $c=17.102(2) \AA, \beta=103.199(5){ }^{\circ}, V=3354.1(7) \AA^{3} . Z$ $=2, d=1.127{\mathrm{~g} . \mathrm{cm}^{-3}}^{-3} \mu=0.449 \mathrm{~mm}^{-1}$. A final refinement on $F^{2}$ with 7927 unique intensities and 321 parameters converged at $\omega R_{F}^{2}=0.1113\left(R_{F}=0.0465\right)$ for 6958 observed reflections with $I$ $>2 \sigma(l)$.

3o.BiNO ${ }_{3}:$ CCDC 1912020, $\mathrm{C}_{67} \mathrm{H}_{56} \mathrm{BiN7O}_{11} \mathrm{~S}, \quad M=1376.22$. Monoclinic $P 21 / c$ (I.T.\#14), $a=13.8772(13), b=33.160(3), c=$ 15.3815(14) $\AA, \beta=93.544(3)^{\circ}, V=7064.5(12) \AA^{3} . Z=4, d=$ $1.294{\mathrm{~g} . \mathrm{cm}^{-3}}^{-3} \mu=2.584 \mathrm{~mm}^{-1}$. A final refinement on $F^{2}$ with 16085 unique intensities and 793 parameters converged at $\omega R_{F}^{2}$ $=0.1564\left(R_{F}=0.0677\right)$ for 13760 observed reflections with $I>$ $2 \sigma(I)$

\section{Acknowledgments}

Région Bretagne is acknowledged for financial support to WB.

Keywords: Coordination modes $\cdot$ bismuth $\bullet$ zinc $\cdot$ hydrogen bonds $\cdot$ conformation analysis

[1] B. Champin, P. Mobian, J. P. Sauvage, Chem. Soc. Rev. 2007, 36, 358-366.

[2] A. Coskun, M. Banaszak, R. D. Astumian, J. F. Stoddart, B. A. Grzybowski, Chem. Soc. Rev. 2012, 41, 19-30.

[3] V. Balzani, A. Credi, M. Venturi Molecular Devices and Machines-A Journey into the Nanoworld; Wiley-VCH: Wenheim, 2003.

[4] Molecular Switches (Ed.: B. L. Feringa), Wiley-VCH, Wenheim, 2001, pp. 281-307.

[5] V. Amendola, L. Fabbrizzi, M. Licchelli, C. Mangano, P. Pallavicini, L. Parodi, A. Poggi, Coord. Chem. Rev. 1999, 190-192, 649-669.

[6] V. Amendola, L. Fabbrizzi, M. Licchelli, C. Mangano, P. Pallavicini, Acc. Chem. Res. 2001, 34, 488-493.

[7] L. Fabbrizzi, F. Foti, S. Patroni, P. Pallavicini, A. Taglietti, Angew. Chem. Int. Ed. 2004, 43, 5073-5077.

[8] B. Colasson, N. Le Poul, Y. Le Mest, O. Reinaud, J. Am. Chem. Soc., 2010, 132, 4393-4398

[9] T. Mashiko, C. A. Reed, K. J. Haller, W. R. Scheidt, Inorg. Chem. 1984, 23, 3192-3196.

[10] S. Ciurli, S. Gambarotta, C. Floriani, A. Chiesi-Villa, C. Guasfini, Angew. Chem. Int. Ed. Engl. 1986, 25, 553-554.

[11] J. Arnold, D. Y. Dawson, C. C. Hoffman, J. Am. Chem. Soc. 1993, 115, 2707-2713.

[12] M. Tsutsui, C. P. Hrung, D. Ostfeld, T. S. Srivastava, D. L. Cullen, E. F. Meyer Jr, J. Am. Chem. Soc. 1975, 97, 3952-3965.

[13] H. Ogoshi, J.-I. Setsune, T. Omura and Z.-I. Yoshida, J. Am. Chem. Soc., 1975, 97, 6461-6466.

[14] H. Ogoshi, J.-I. Setsune and Z.-I. Yoshida, J. Organomet. Chem., 1978, 159, 317-328.

[15] K. M. Kadish, Y. J. Deng, C.-L. Yao and J. E. Anderson, Organometallics, 1988, 7, 1979-1983.

[16] J. J. Lai, S. Khademi, E. F. Meyer Jr, D. L. Cullen, K. M. Smith, J. Porphyrins Phthalocyanines 2001, 5, 621-627. 
[17] T. Kohler, M. C. Hodgson, D. Seidel, J. M. Veauthier, S. Meyer, V. Lynch, P. D. W. Boyd, P. J. Brothers and J. L. Sessler, Chem. Commun., 2004, 1060-1061.

[18] P. J. Brothers, Inorg. Chem., 2011, 50, 12374-12386.

[19] I. Beletskaya, V. S. Tyurin, A. Y. Tsivadze, R. Guilard, C. Stern, Chem. Rev. 2009, 109, 1659-1713.

[20] C. M. Lemon, P. J. Brothers, B. Boitrel, Dalton Trans. 2011, 40, 65916609.

[21] S. Le Gac, B. Boitrel, J. Porphyrins Phthalocyanines 2012, 16, 537-544.

[22] S. Le Gac, B. Najjari, L. Fusaro, T. Roisnel, V. Dorcet, M. Luhmer, E. Furet, J.-F. Halet, B. Boitrel, Chem. Commun. 2012, 48, 3724-3726.

[23] B. Najjari, S. Le Gac, T. Roisnel, V. Dorcet, B. Boitrel, J. Am. Chem. Soc. 2012, 134, 16017-16032.

[24] S. Le Gac, V. Dorcet, L. Fusaro, B. Boitrel, Chem. Eur. J. 2013, 19, 13376-13386.

[25] S. Le Gac, B. Boitrel, New J. Chem. 2016, 40, 5650-5655.

[26] N. Motreff, S. Le Gac, M. Luhmer, E. Furet, J.-F. Halet, T. Roisnel, B. Boitrel, Angew. Chem. Int. Ed. 2011, 50, 1560-1564.

[27] S. Le Gac, B. Najjari, V. Dorcet, T. Roisnel, L. Fusaro, M. Luhmer, E. Furet, J.-F. Halet, B. Boitrel, Chem. Eur. J. 2013, 19, 11021-11038.

[28] S. Le Gac, L. Fusaro, T. Roisnel, B. Boitrel, J. Am. Chem. Soc. 2014, 136, 6698-6715.

[29] V. Ndoyom, L. Fusaro, V. Dorcet, B. Boitrel, S. Le Gac, Angew. Chem. Int. Ed. 2015, 54, 3806-3811.

[30] V. Ndoyom, L. Fusaro, T. Roisnel, S. Le Gac, B. Boitrel, Chem. Commun. 2016, 52, 517-520

[31] S. Le Gac, V. Ndoyom, L. Fusaro, V. Dorcet, B. Boitrel, Chem. Eur. J. 2019, 25, 845-853.

[32] A. Didier, L. Michaudet, D. Ricard, V. Baveux-Chambenoit, P. Richard, B. Boitrel, Eur. J. Org. Chem. 2001, 1917-1926.

[33] Note that the "in" and "out" labelling has been initially chosen with the strap in the broken-shape conformation when no X-ray structure of this series was yet available, see previous reference. We now know that most of these ligands adopt the $\mathrm{W}$-shape conformation even without any coordination driving force.

[34] Z. Halime, M. Lachkar, T. Roisnel, P. Richard, B. Boitrel, Inorg. Chem. 2007, 46, 6338-6346.

[35] I. Hijazi, T. Roisnel, P. Even-Hernandez, E. Furet, J.-F. Halet, O. Cador, B. Boitrel, J. Am. Chem. Soc. 2010, 132, 10652-10653.

[36] M. Hanana, H. Arcostanzo, P. K. Das, M. Bouget, S. Le Gac, H. Okuno, R. Cornut, B. Jousselme, V.Dorcet, B. Boitrel, S. Campidelli, New. J. Chem. 2018, 42, 19749-19754.

[37] Z. Halime, M. Lachkar, T. Roisnel, E. Furet, J.-F. Halet, B. Boitrel, Angew. Chem. Int. Ed. 2007, 46, 5120-5124.

[38] Z. Halime, S. Balieu, M. Lachkar, T. Roisnel, P. Richard, B. Boitrel, Eur. J. Org. Chem. 2006, 1207-1215.

[39] It is worth to remind that typical graphic abaci have been calculated only in specific cases using the classical ring current incorporating two circular loops crossing the macrocyclic plane. In this type of graph, the iso-shielding lines indicating the incremental shift values $(\Delta, \mathrm{ppm})$ result from the plot of the out-of-plane coordinate $(z, \AA)$ against the radial distance from the center of the porphyrin $(p, \AA)$. For more details, see H. Scheer and J. J. Katz In Porphyrins and Metalloporphyrins, K. M. Smith (Ed.) Elsevier, Amsterdam, 1975, pp. 399-524.
[40] Coordination studies with bis-strap ligands 40o, 4io and $4 \mathbf{i i}$ will be reported in due time.

[41] B. Boitrel, Z. Halime, L. Michaudet, M. Lachkar, L. Toupet, Chem. Commun. 2003, 2670-2671.

[42] N. Yang, J. A. Tanner, Z. Wang, J.-D. Huang, B.-J. Zheng, N. Zhua, H. Sun, Chem. Commun. 2007, 4413-4415.

[43] L. Michaudet, P. Richard, B. Boitrel, Chem. Commun. 2000, 15891590.

[44] B. Boitrel, M. Breede, P. J. Brothers, M. Hodgson, L. Michaudet, C. E. F. Rickard, N. Al Salim, Dalton Trans. 2003, 1803-1807

[45] G. M. Sheldrick, Acta Cryst. 2015, A71, 3-8.

[46] G. M. Sheldrick, Acta Cryst. 2015, C71, 3-8.

[47] P. v.d. Sluis, A.L. Spek, Acta Cryst., 1990, A46, 194-201.

[48] A. L. Spek, J. Appl. Cryst., 2003, 36, 7-13.

[49] A. L. Spek, J. Appl. Cryst., 2015, C71, 9-18. 


\section{Entry for the Table of Contents}

\section{FULL PAPER}

A new family of overhanging carboxylic acid strap porphyrins exhibits significant flexibility of the strap, tuned by coordination, resulting in inward (for Zn(II)) or outward (for $\mathrm{Bi}(\mathrm{III}))$ orientation of the overhanging carboxylic acid function.

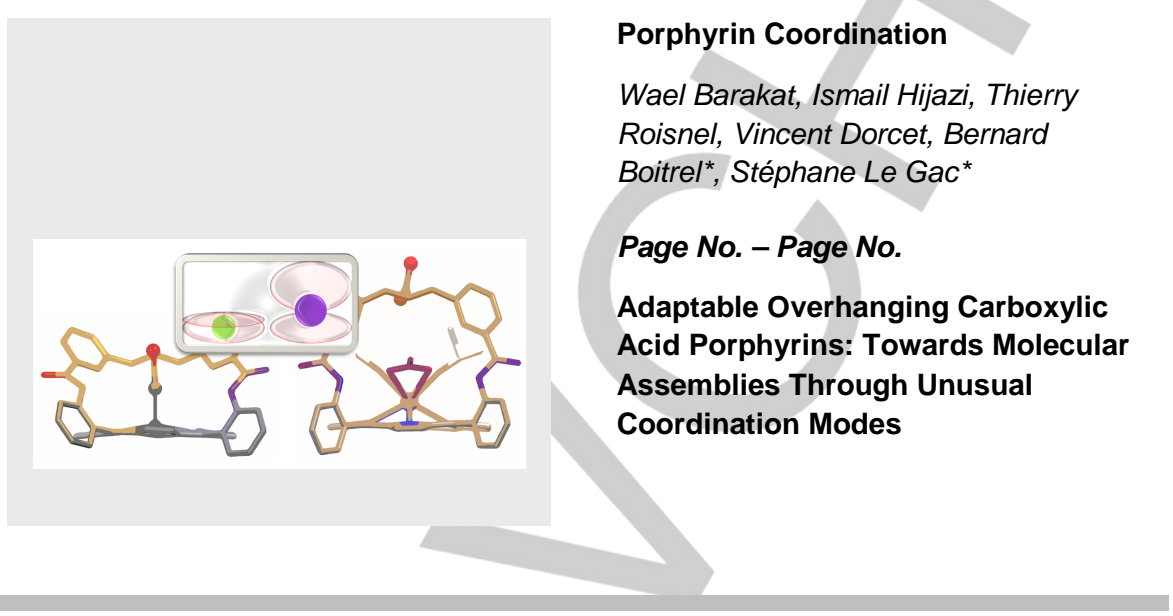

